$D_{R .243}$

LA-7299-M

Manual

UC.32

Issued: May 1978

A Microprocessor-Controlled CAMAC Data Link Module Jerry M. Potter

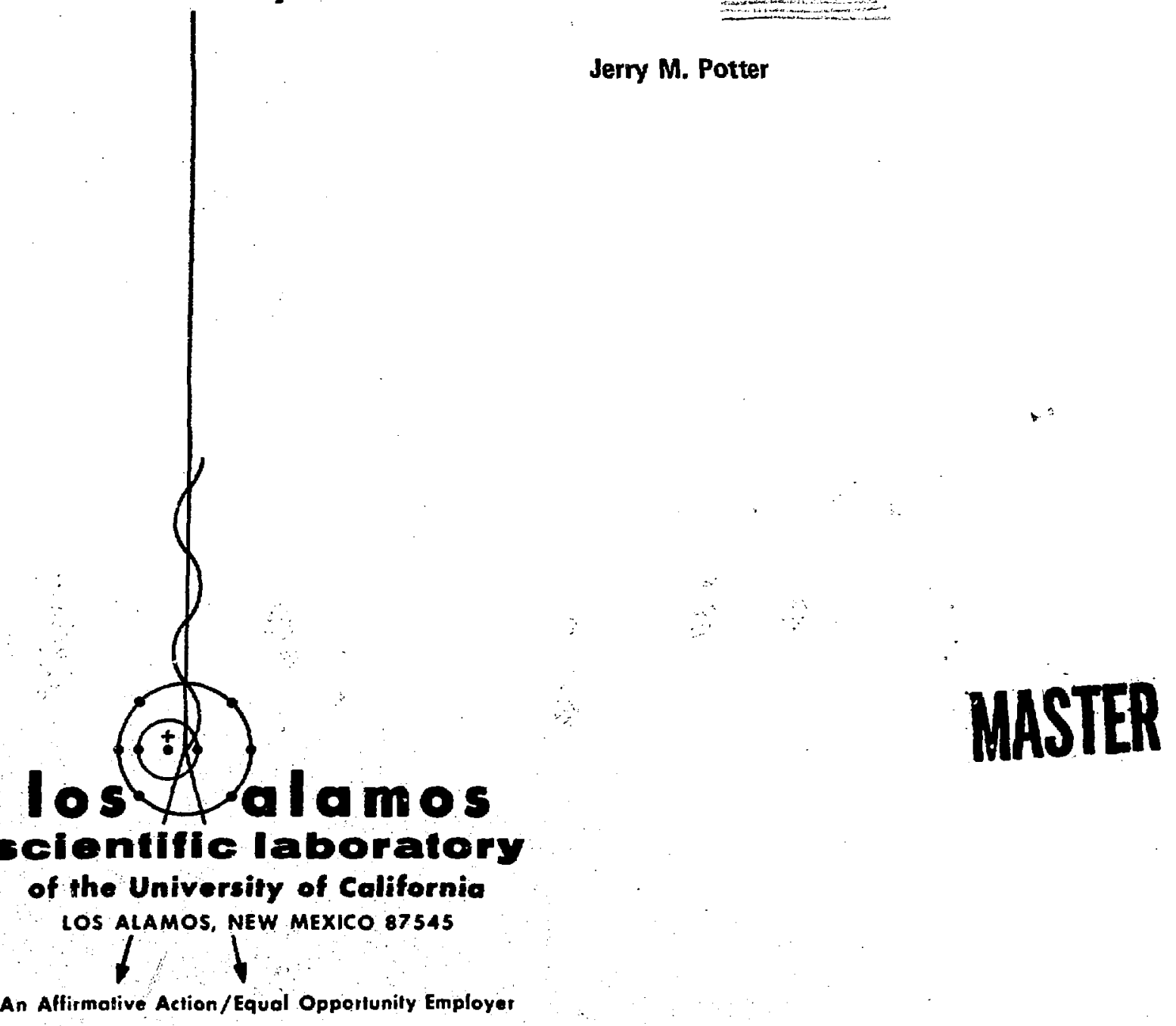

An Affirmative Action/Equal Opportunity Employer

DEPARTITEDETATE:

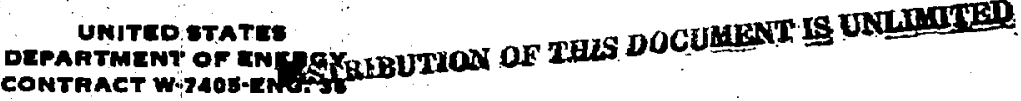




\section{CONTENTS}

ABSTRACT ........................ 1

I. PURPOSE .................. 1

II. DESCRIPTION .............. 1

up-DL Timing .............. 4

Used With ........... 4

Front Panel ........... 5

Power Requirements ....... . 5

Physical Description ........ 5

Software ........... . 6

Micro Data Link CAMAC Commands . . . . 6

Micro Data Link Reset Signals . . . . . 7

Micro Data Link - I/0 Addressing .... 8

Micro Data Link Interrupt Structure ... 9

Micro Data link CAMAC Control Status

Register ......... 10

Micro Data Link Control Status Register. . 1

Micro Data Link Memory i/0 . . . . . 13

up-DL, Il Pin Assignments . . . . . 16

LAMPF Data Link Cable Wiring . . . . . 17

APPENDIX A. Logical Flow Diagrams . . . . . A-1

APPENDIX B. Program Lịsting ........ B-1

Thin teport wo wice

The teport win preparad a an ecoorat of work

Uhived State not the Unies Conemmenc. Nefther the

Enerna, wor ary of thetriat Stutes Department of

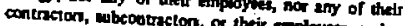

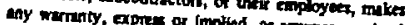

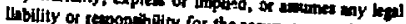

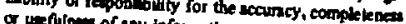

procen she of any hsomution, upparater, prodoct of

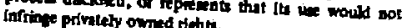




\title{
A MICROPROCESSOR-CONTROLLED CAMAC DATA LINK MODULE
}

\author{
by
}

Jerry M. Potter

\begin{abstract}
Communication between the central control computer and remote, satellite data-acquisition/control stations at the Clinton P. Anderson Meson Physics Facility (LAMPF) is presently accomplished through the use of CAMAC-based Data Link modules. With the advent of the microprocessor, a new philosophy for digital data communications has evolved. Data Link modules containing microprocessor controllers provide link management and communication network protocol through algorithms executed in the Data Link microprocessor.
\end{abstract}

\section{PURPOSE}

Communications between the central control computer and remote satellite data-acquisition/control stations at LAMPF have been effected through CAMACbased Data Link modules located in CAMAC crates associated with each computing system. Control of the link, management of communications protocol, and message synchronization between two systems are under the control of algorithms residing in each controlining computer.

As the work load of the central control computer increased, it became evident that the system overhead created by the management of several Data Links would soon become intolerable.

The Data Link hardware, used in communications between the LAMPF central control computer and several satellite processing stations, was originaliy packaged in the CANAC standard to make use of the computer independence associated with the CAMAC interface. A logical extension of the Data Link, and a solution to the overloading problem created by link management algorithms, lay in the appropriate use of microprocessor control within the Data Link.

\section{DESCRIPTION}

The system configuration, indicated in Fig. 7 , is a radial coupling of satellite processor stations to the system controller (the central control computer). 


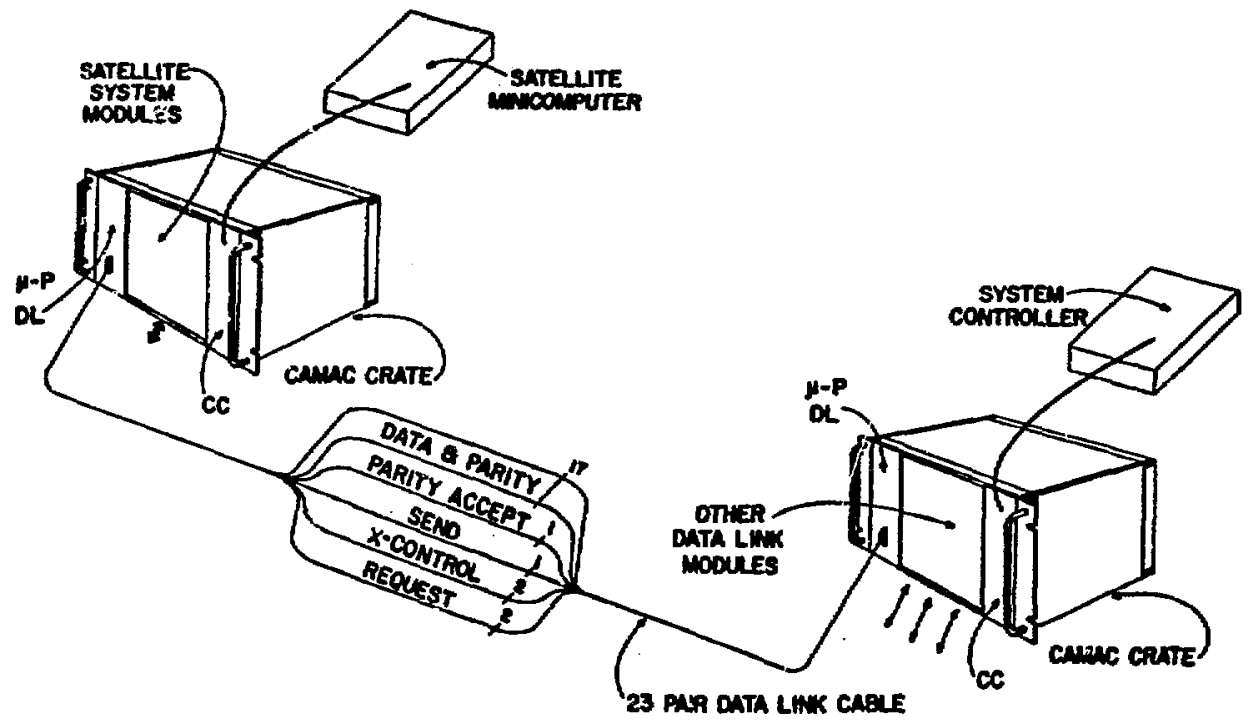

Fig. 1. CAMAC/u-processor data link system configuration.

The communications channel between two identical microprocessor Data Link. modules ( $\mu p-D L)$ consists of a 23-pair cable for bidirectional data flow, error control, and request/priority handling. A parallel channel was originally chosen owing to the data transfer rates desired; thus; a parallel channel was also chosen for the $\mu \mathrm{p}-\mathrm{DL}$ for compatibility and to maintain data through-put.

The communication contrnl algorithms required for the $\mu \mathrm{p}-\mathrm{DL}$ are split between the computer and its associated CAMAC-based link. Systems on either end of the communications channel must contain algorithms to load and initiate transfer of message, and to accept a received message. Figure 2 contains a simplified flow diagram for a computer and the associated $\mu \mathrm{p}-\mathrm{DL}$.

The system controller must determine if the $\mu \mathrm{p}-\mathrm{DL}$ is busy, and if not, write the message to be transferred into a message buffer contained within the $\mu \mathrm{p}-\mathrm{DL}$. An instruction to initiate transfer is the only other action required by the controlling computer.

The transfer initiate instruction from the controlling computer causes the incernal microprocessor in the Data Link module to be interrupted and begin the task of gaining control of the communications channel, synchronizing to the $\mu \mathrm{P}-\mathrm{DL}$ at the other end, and sending the message stored in the message buffer. Error control in message transfer is handled by the two $\mu \mathrm{p}-\mathrm{DL}$ modules. If an error occurs, as signified by $A C K / N A K$ codes from a receiving $\mu \mathrm{p}-\mathrm{DL}$, the sending $\mu \mathrm{P}-\mathrm{DL}$ will attempt a retransmission up to ten times before aborting and informing the controlling computer. In either case, the sending $\mu \mathrm{p}-\mathrm{DL}$ will generate a LAM via the CAMAC interface to signify completion to the controlling computer.

During the synchronization and control process of ä sending $\mu \mathrm{p}-\mathrm{DL}$, the receiving link microprocessor is signaled via an interrupt that a transfer is about to begin. Onty after the successfut receipt of a message does the receiving $\mu \mathrm{p}-\mathrm{DL}$ signal the receiving computer (by LAM via the CAMAC interface) that a message is present in the message buffer for reading. 


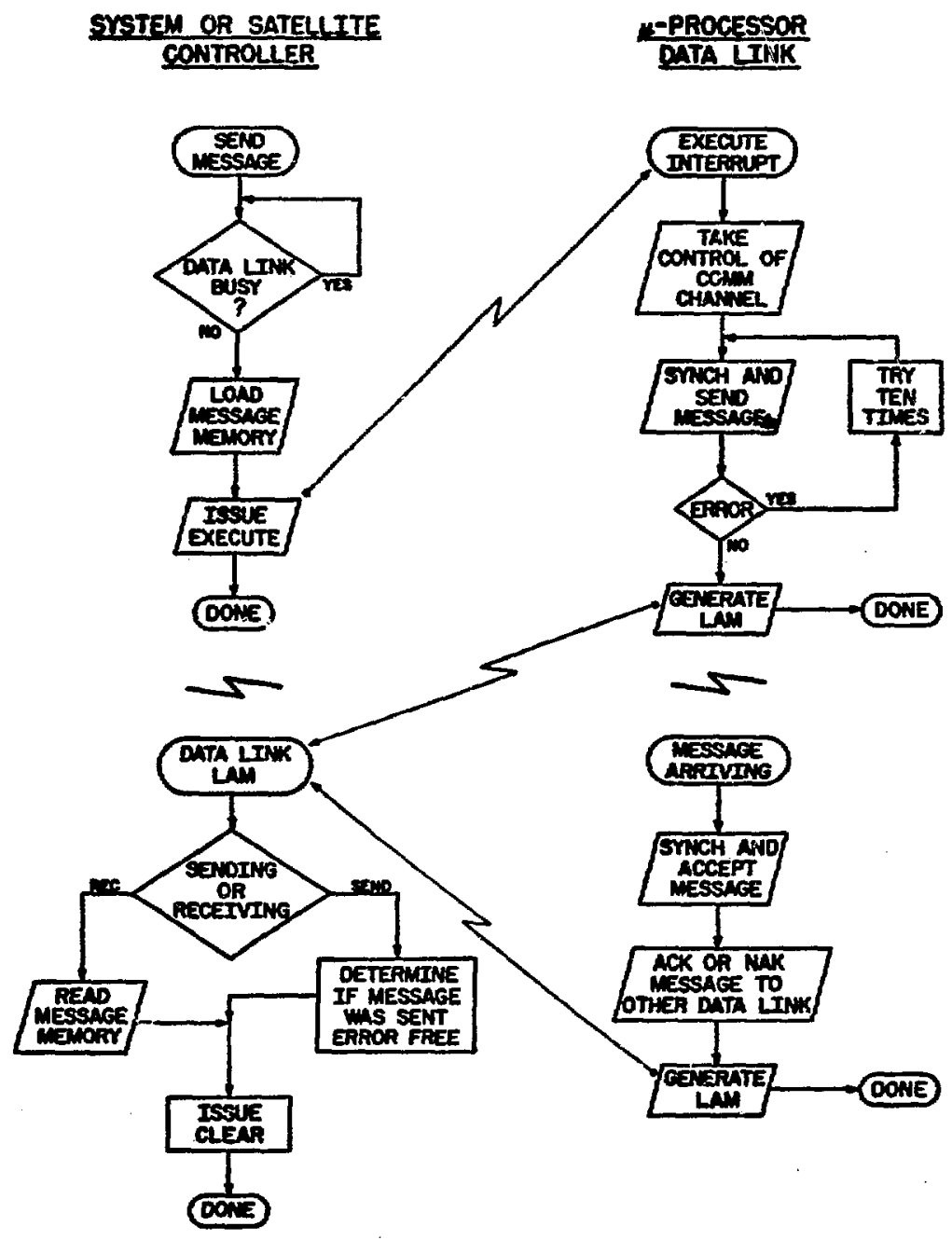

Fig. 2. CAMAC/ $\mu$-processor data link simplified algorithm flow.

The LAM service routine for either sending-complete or received-message is identical in buth computer systems at either end of the communication channel.

The block diagram of the $\mu \mathrm{p}-\mathrm{DL}$ module is shown in Fig. 3. The central feature is the INTEL $8080^{\circ}$ microprocessor interfaced to a two-bus structure, the RW Bus and the BRW Bus.

A set of CAMAC functions has been decoded for handling of the $\mu \mathrm{P}-\mathrm{DL}$ by the CAMAC interface and controlling computer. LAM logic and a Control/Status Register (CSR) complete the necessary CAMAC connections.

Internal to the $\mu \mathrm{p}-\mathrm{DL}$, a coupled two-bus structure provides the required paths for data flow during loading of the message buffer, sending, and receiving of a message. The RW Bus connects the CAMAC write-lines, the message buffer, two 8-bit I/0 ports from the 8080 (to make up a 16-bit internal word), the link receiver, and finally, a path to the BRW Bus. Gating of information onto the RW Bus is mutually exclusive and accomplished through tri-state logic. 


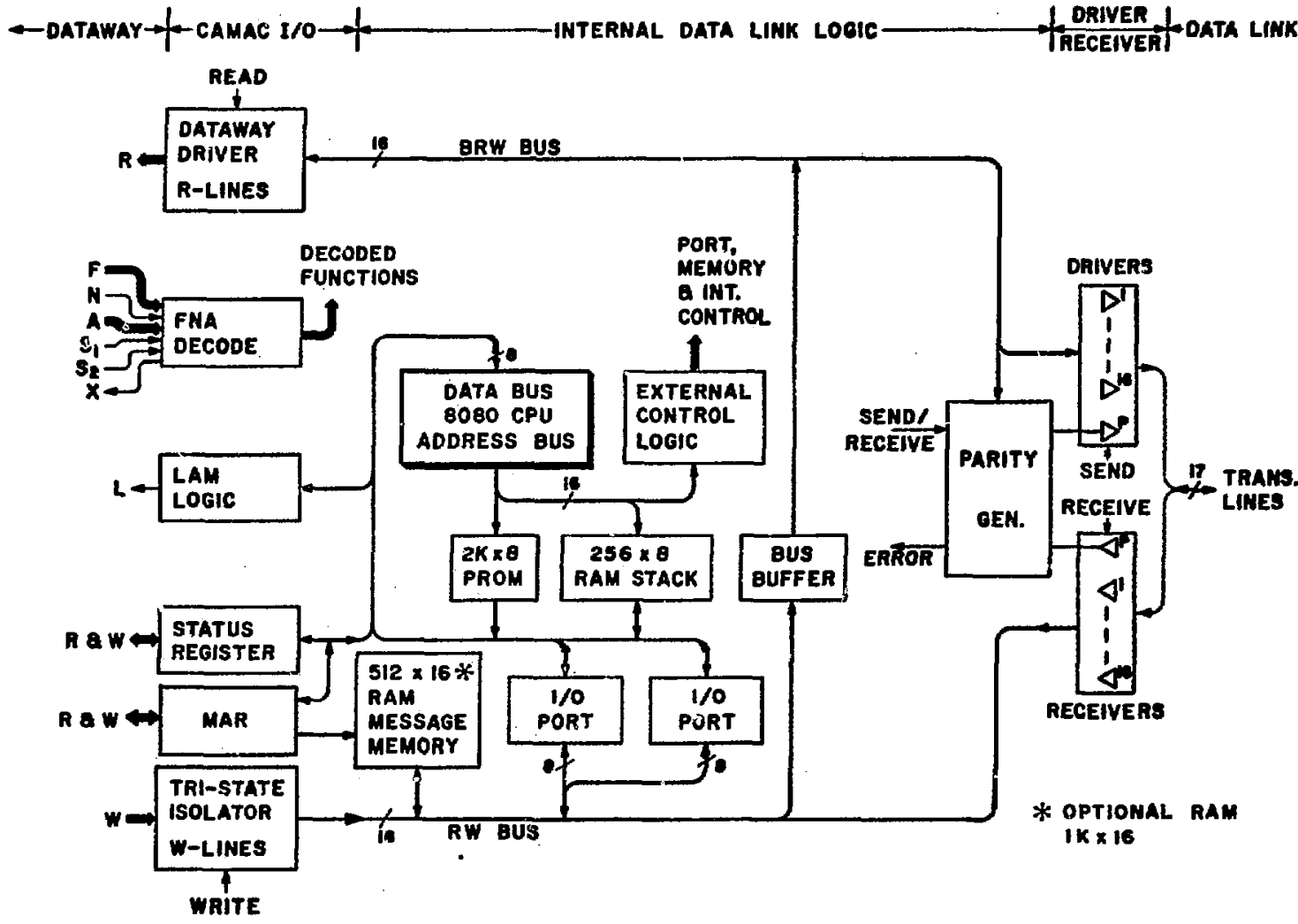

Fig. 3. CAMAC/u-processor data link organization.

The BRW Bus serves to couple the CAMAC read-lines, a parity generator (used in both receiving and sending for odd-parity across a word), and the link drivers.

The communications algorithms, residing in PROM memory and executed by the $8080 \mathrm{CPU}$, control the internal data flow over the two-bus structure, in addition to the main task of establishing communications with, and synchronizing to, the other $\mu \mathrm{p}-\mathrm{DL}$.

$\underline{\mu p-D L ~ T i m i n g}$

A message timing sequence is illustrated in Fig. 4. The figure indicates the start of a message transfer transaction by a sending $\mu \mathrm{p}-\mathrm{DL}$ and relates the various steps to the receiving $\mu \mathrm{p}-\mathrm{DL}$.

A "handshake" sequence of SEND-MESSAGE HERE-ACCEPT-ACKNOWLEDGE between the two links provides the necessary synchronization. An arithmetic check sum is sent as the final word and signified by a lowering of REQUEST TO SEND by the sending $\mu \mathrm{p}-\mathrm{DL}$. The receiving $\mu \mathrm{P}-\mathrm{DL}$ waits until REQUEST TO SEND is again asserted before returning an ACKnowledge or a NAK (negative acknowledge). The LAMs to each computer take place after the final transaction (ACK or NAK).

Used with

The $\mu \mathrm{p}-\mathrm{DL}$ can be used in any CAMAC system and can communicate with another $\mu p-D L$ or an old "dumb" Data Link where system overhead is not a problem such as in the satell ite processors. 


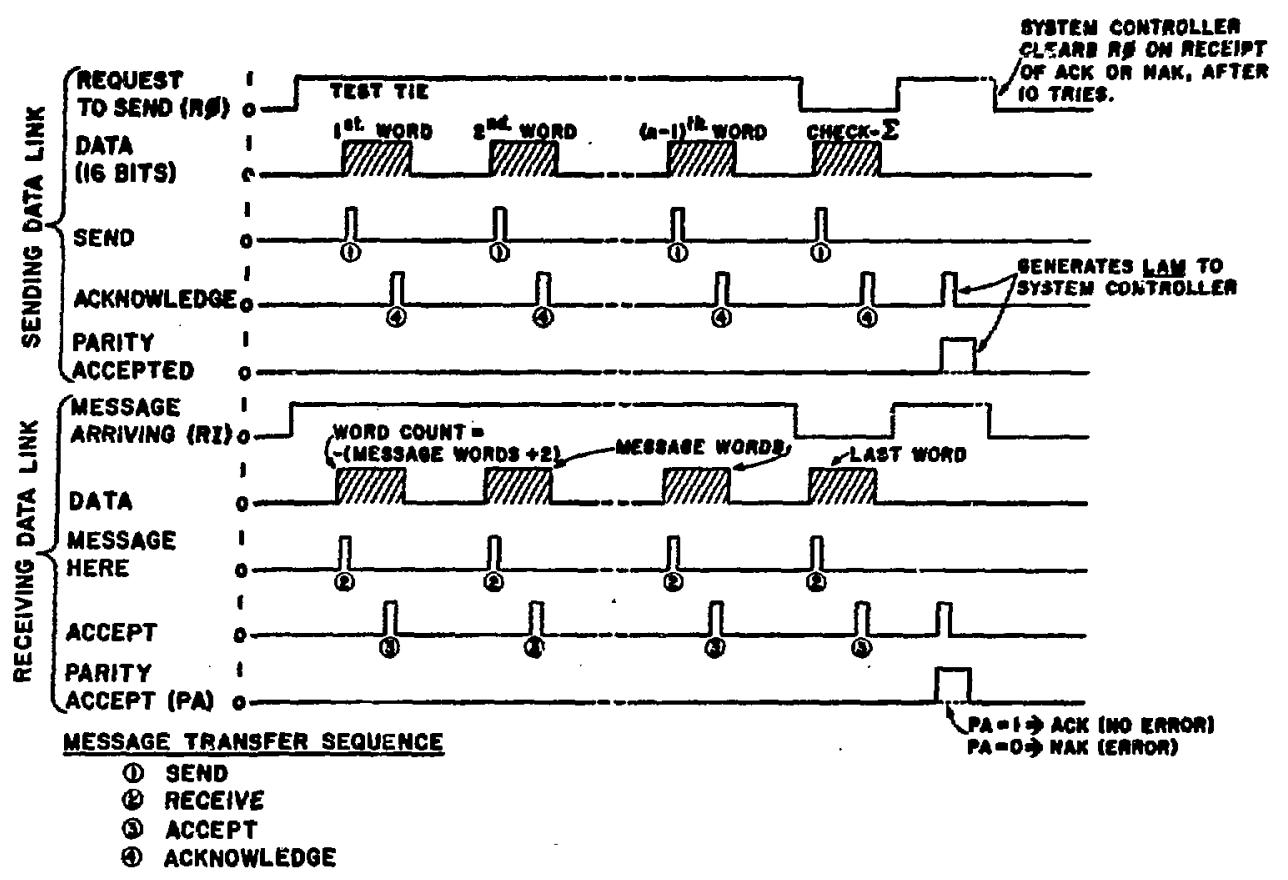

Fig. 4. CAMAC/ $\mu$-processor data link communications channel transactions.

\section{Front Panel}

LEDs $N$ Indicates that the $\mu p-D L$ is being addressed

LE LAM ENABLE

LS LAM SOURCE

BUSY Indicates that the $\mu \mathrm{p}-\mathrm{DL}$ is BUSY

CONNECTOR - J1-AMP \#205211-1 (Data Link connector)

CONTROLS - There is a RESET pushbutton mounted below the Data Link connector. A RESET will reinitialize the $\mu \mathrm{p}-\mathrm{DL}$.

Power Requirements

$\mu \mathrm{p}-\mathrm{DL}$, Board No. 1

1 A at $+6 \mathrm{~V}, 45$ ma at $-6 \mathrm{~V}, 115$ ma at $+24 \mathrm{~V}$

up-DL, Board No. 2

$1.9 \mathrm{~A}$ at $+\overline{6} \mathrm{~V}, 11 \mathrm{ma}$ at $-6 \mathrm{~V}$

\section{Physical Description}

The $\mu \mathrm{p}-\mathrm{DL}$ module resides in a two-wide CAMAC frame. The controlling station is the left-hand slot of the module. 
The left-hand side of the $\mathrm{pp}-\mathrm{DL}$ module is made up of four pc boards. The board nearest the front is a DUAL PROGRAMMABLE PERIPHERAL INTERFACE BOARD (LAMPF Dwg. No. 63Y-125952). The second pc board from the front is the CENTRAL PROCESSING UNIT AND MEMORY BOARD (LAMPF DWg. No. 63Y-125945). The third pc board from the front is the INTERRUPT STRUCTURE CARD (LAMPF Dwg. No. 63Y-149705.) The fourth pc board is the up-DL, Board No. 1 (LAMPF Dwg. No. 63Y-149106). The board connects to the CAMAC dataway and contains the CAMAC decode logic, LAM logic, and part of the Data Link control logic.

The right-hand side of the $\mu \mathrm{p}-\mathrm{DL}$ module contains one large pc board, $\mu \mathrm{p}-\mathrm{DL}$, Board No. 2 (LAMPF Dwg. No. 63Y-149124). This pc board contains additional control logic, the Control Status Register (CSR), the RAM Message Buffer, the Memory Address Register (MAR), Bus Buffers, CAMAC Read/Write logic, LAM control logic, Data Link I/0 logic, and the parity logic.

The drawings listed here are available from the author.

Software

Logical flow diagrams are provided in Appendix A. An assembly listing of the $\mu \mathrm{p}-\mathrm{DL}$ software is provided in Appendix $\mathrm{B}$.

MICRO DATA LINK CAMAC COMMANDS

\begin{tabular}{|c|c|c|}
\hline Command & Mnemonic & Operation \\
\hline$F(0) A(0)$ & $\mathrm{RDR}$ & $\begin{array}{l}\text { *READ RAM (Message Buffer) and Increment the Memory } \\
\text { Address Register on S2 }\end{array}$ \\
\hline$F(0) A(1)$ & RCSR & Reads the Control Status Register \\
\hline$F(0) A(2)$ & RDMAR & Reads the Memory Address Register (R10-R1) \\
\hline$F(1) A(15)$ & RDI & Reads the Module Identifier $\left(100_{8}\right)$ \\
\hline$F(9) A(0)$ & CLR & Clear Registers and Restart the CPU \\
\hline$F(10) A(0)$ & CLM & Clear LAM Source \\
\hline$F(16) A(0)$ & WTR & $\begin{array}{l}\text { *LOAD RAM (Message Buffer) and Increment the Memory } \\
\text { Address Register on } \mathrm{S} 2\end{array}$ \\
\hline$F(16) A\langle 1\rangle$ & WCSR & Writes the Control Status Register \\
\hline$F(16) A(2)$ & WMAR & Writes the Memory Address Register (W10-W1). Must \\
\hline$F(25) A(0)$ & SEND & Send Data Link Message \\
\hline$F(25) A(1)$ & TRM & Test RAM (Message Buffer) \\
\hline$F(25) A(2)$ & DNLNLD & $\begin{array}{l}\text { Execute a Down Line Load to a PDP- } 11 \text { (PDP-11 DOS Load } \\
\text { Mode Format) }\end{array}$ \\
\hline
\end{tabular}

A11 furctions gated with $\mathrm{Ni}$ and $\mathrm{S} 1$ or S2 where appropriate.

$X=1$ For all valid commands to module unless $X I$ is set, which will cause the Dataway " $X$ " response to be " 0 " on the next dataway cycle to the up-DL modite.

$Q=0$ For all commands to module.

Z.S2 Initialize - General Reset.

Power-Up - General Reset.

*The Data Link RAM (Message Buffer) is $512 \times 16$ or optional $1024 \times 16$. 
MICRO DATA LINK RESET SIGNALS

PWR-UP:

Resets the Dual Programmable Peripheral Interface Board

$Z+$ PWR-UP:

Generates a RESET Signa]

Clears LAM Enable

Clears the Memory Address Register

RESET

$=Z+P W R-U P+F(9) A(0) \cdot D S 1+$ Manual Reset

RESET:

Restarts the $8080 \mathrm{CPU}$ at location zero

Clears LAM Source

Clears XI (X-IN from other Data Link)

Sets Data Link Busy

CL1:

Clears LAM Source

Clears XI (X-IN from other Data Link)

Clears Data Link Busy

$C L 1+Z+P W R-U P:$

Clears Recejve Enable

Clears Send Enable

Clears RO - Request Out

Clears XOC - X-OUT-Control

Clears LCI - LAM Control In

Clears PAIN - Parity Accept In

Clears BEIN - Block Error In

Clears All Interrupts

$F(10) A(0):$

Clears LAM Source

RMAR:

Clears the Memory Address Register

CLI and RMAR are generated only from the 8080 CPU. 
Isolated I/O (Linear Select)

Address Bits $A 0$ and $A 1$ are Port Selects for the $8255 \mathrm{~A}$ Programmable Peripheral Interface Units.

Address Bits A2 through A7 are used for Device Select. Each Bit is assigned as the exclusive enable for a specific $I / 0$ device and is Active Low.

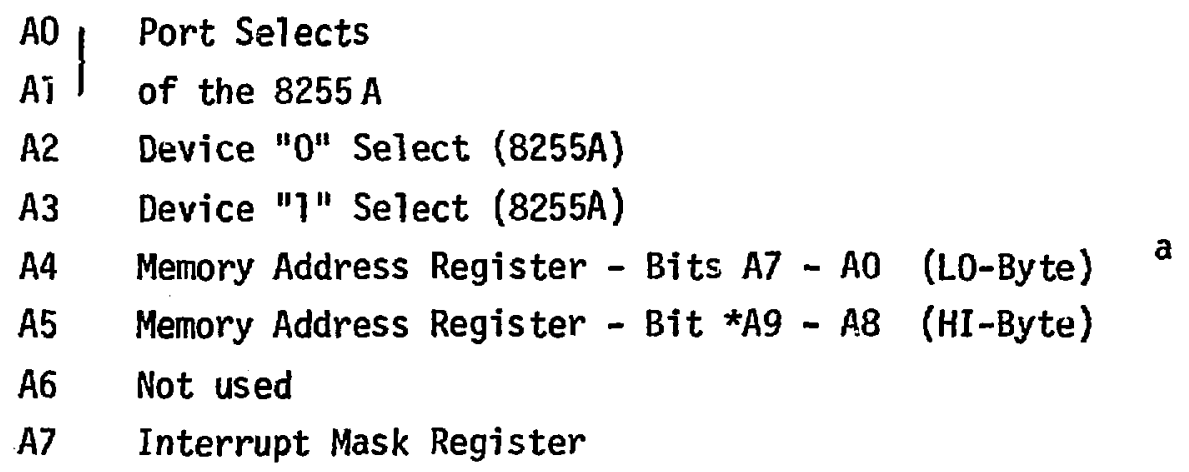

*The Data Link RAll is $512 \times 16$, or $1024 \times 16$ is optional.

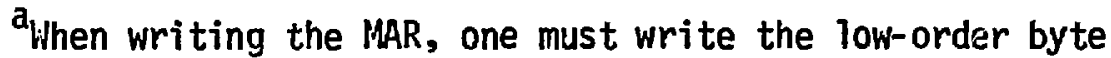
first and then the high-order byte; otherwise, the high byte may be incremented.

Device "O": $\begin{aligned} \text { CONTROL ADDRESS } & =\mathrm{FBH} \\ \text { CSRA ADDRESS } & =\mathrm{F} 8 \mathrm{H} \\ \text { CSRB ADDRESS } & =\mathrm{B} 9 \mathrm{H} \\ \text { CSRC ADDRESS } & =\mathrm{FAH}\end{aligned}$

Device " $7 ":$ CONTROL ADDRESS $=$ F7H

DATAL ADDRESS $=F 4 \mathrm{H}$

DATAH ADDRESS $=F 5 \mathrm{H}$

DATAC ADDRESS $=$ F6H

MICROPROCESSOR RAM $=3$ DOO THROUGH 3DFF. 
MICRO DATA LINK INTERRUPT STRUCTURE

INTR 7 Not used

INTR $6 \quad X I$

INTR 5 Down-Line Load

INTR 4 Send DL Msg.

INTR 3 Test RAM

INTR 2 Write CSR

INTR 1 RI

INTR $0 \quad$ Not used
HIGHEST PRIORITY

*

$F(25) A(2)$

$F(25) A(0)$

$F(25) A(1)$

$F(16) A(1)$

LOWEST PRIORITY

*Wi11 cause the Dataway " " response to be " 0 " on the next dataway cycle to the $\mu \mathrm{p}-\mathrm{DL}$ module.

INTERRUPT MASK:

The INTERRUPT MASK REGISTER ADDRESS $=7 F H$.

A logical "1" written into the MASK REGISTER

will MASK OFF the corresponding interrupt line.

MASK BIT INTERRUPT

D7

INTR7

D6

INTR6

D5

INTR5

D4

INTR4

D3

INTR3

D2

INTR2

D1

[NTR ]

DO

INTRO 
MICRO DATA LINK CAMAC CONTROL STATUS REGISTER

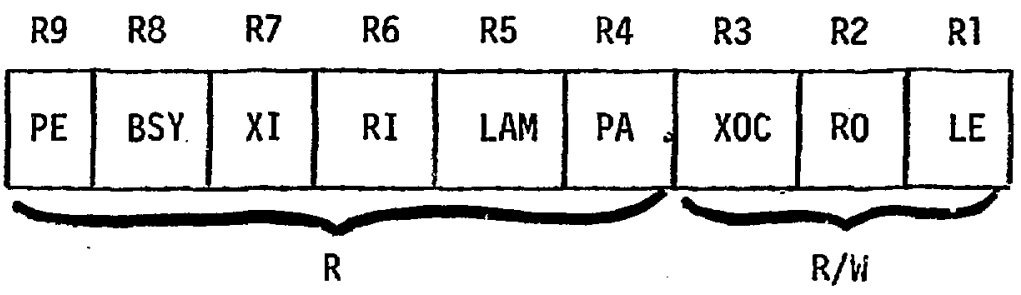

CAMAC COMMAND

$F(16) A(1)$ WRITES THE CSR

$F(0) A(1)$ READS THE CSR

Mnemonic

R/W1 :

LE

RO

XOC

PA

LAM

RI

XI

BSY

PE
Operation

LAM ENABLE

WRITE/READ

REQUEST OUT

WRITE/READ ${ }^{\mathrm{a}}$

$X$-OUT CONTROL

WRITE/READ ${ }^{b}$

PARITY ACCEPT

READ ONLY

LAM STATUS

READ ONLY

READ ONLY

READ ONLY

READ ONLY

READ ONLY

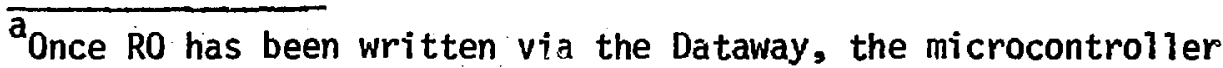
takes over control of the RO line and then it can only be read and not cleared or set via the Dataway.

${ }_{\text {xOC: }} \mathrm{X}$-Out control will send $\mathrm{X}$-control $=0$ to be detected on the next cycle in the other module.
} 
MICRO DATA LINK CONTROL STATUS REGISTER

PROGRAMMABLE PERIPHERAL INTERFACE: 8255A - DEVICE 0

CONTROL WORD FOR CSR I/O (91H)

CONTROL ADDRESS $=$ FBH

\begin{tabular}{|l|l|l|l|l|l|l|l|l|}
\hline $\mathrm{D} 7$ & $\mathrm{D} 6$ & $\mathrm{D} 5$ & $\mathrm{D} 4$ & $\mathrm{D3}$ & $\mathrm{D} 2$ & $\mathrm{D} 1$ & $\mathrm{D} 0$ \\
\hline 1 & 0 & 0 & 1 & 0 & 0 & 0 & 1 \\
\hline
\end{tabular}

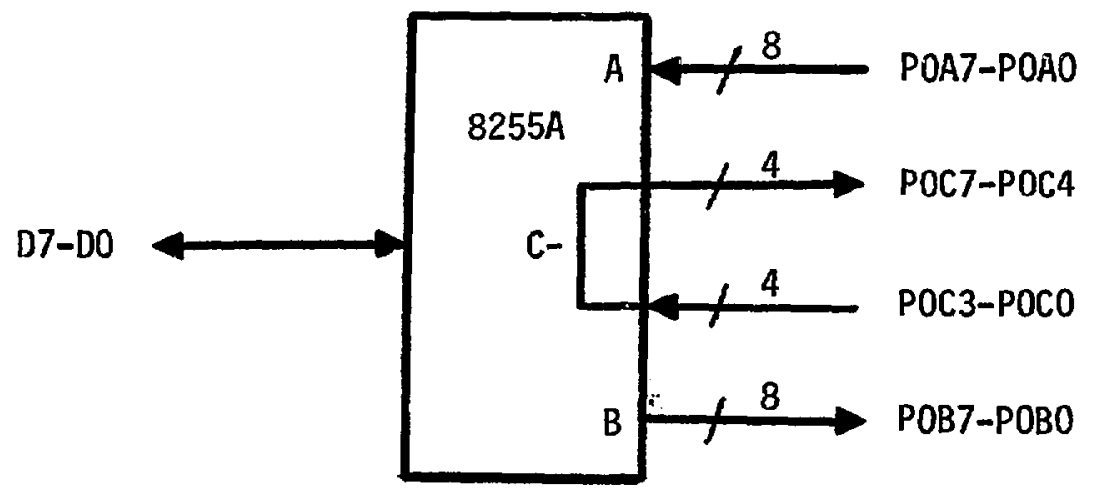

$$
\begin{array}{ll}
\text { D0 }=1 & \text { Port C (Lower) - INPUT } \\
\text { D1 }=0 & \text { Port B - OUTPUT } \\
\text { D2 }=0 & \text { Group B - MODE "0" } \\
\text { D3 }=0 & \text { Port C (Upper) - OUTPUT } \\
\text { D4 }=1 & \text { Port A - INPUT } \\
\text { D5 }=0 & \text { Group A - MODE "0" } \\
\text { D6 }=0 & \\
\text { D7 }=1 & \text { Mode Set Flag - Active }
\end{array}
$$


PROGRAMABLE PERIPHERAL INTERFACE: 8255A - DEVICE O

INPUT CSR

POC3 POC2 POC1 POCO POA7 POA6 POA5 POA4 POA3 POA2 POA7 POAO

\begin{tabular}{|l|l|l|l|l|l|l|l|l|l|l|l|}
\hline & & & $B E$ & $B S Y$ & $X I$ & RI & LCI & PAIN & $X O C$ & RO & LE \\
\hline
\end{tabular}

POAO: LE LAM ENABLE

POA1: RO REQUEST OUT

POA2: XOC X-OUT-CONTROL

POA3: PAIN PARITY ACCEPT IN

CSRA ADDRESS $=F 8$

CSRC ADDRESS $=$ FA

POA4: LCI LAM CONTROL IN

POA5: RI REQUEST IN

POA6: XXI X-IN

POA7: BSY BUSY

POCO: BE BLOCK ERROR

QUTPUT CSR

POC7 POC6 POC5 POC4 POB7 P0B6 POB5 P0B4 POB3 POB2 POB1 POB0

\begin{tabular}{|l|l|l|l|l|l|l|l|l|l|l|l|}
\hline $\begin{array}{c}\text { I/0 } \\
\text { FLAG }\end{array}$ & & PE & ROC & & CLI & RMAR & IMAR & LAMO & LCO & PA & XO \\
\hline
\end{tabular}

POBO: $\quad X O \quad X$-OUT

POB1: PA PARITY ACCEPT

POB2: LCO LAM CONTROL OUT

CSRB ADDRESS $=$ F9

POB3: LAMO LAM OUT

CSRC ADDRESS $=F A$

POB4: IMAR INC THE MAR

POB5: RMAR RESET THE MAR

POB6: CLT CLEAR 1

POC4: ROC REQUEST OUT CONTROL

POC5: PE PARITY ERROR

POC7: IOF I/O FLAG 
PROGRAMMABLE PERIPHERAL INTERFACE: 8255A-DEVICE I

CONTROL WORD FOR A-READ OPERATION (9BH)

CONTROL ADDRESS $=$ F7H

$\begin{array}{llllllll}D 7 & D 6 & D 5 & D 4 & D 3 & D 2 & D 1 & D 0\end{array}$

\begin{tabular}{|l|l|l|l|l|l|l|l|}
\hline 1 & 0 & 0 & 1 & 1 & 0 & 1 & 1 \\
\hline
\end{tabular}

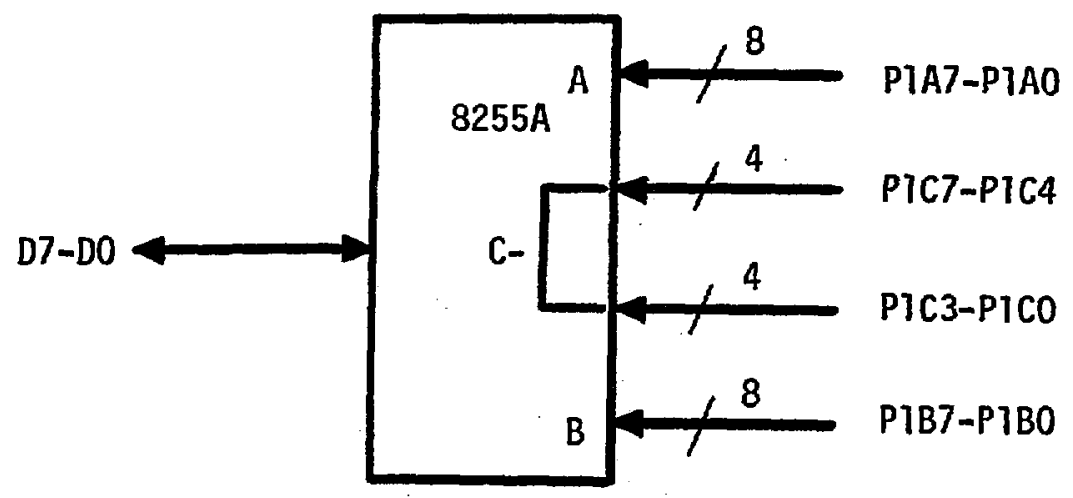

$$
\begin{array}{ll}
\text { D0 }=1 & \text { Port C (Lower) - INPUT } \\
\text { D1 }=1 & \text { Port B - INPUT } \\
\text { D2 }=0 & \text { Group B - MODE "O" } \\
\text { D3 }=1 & \text { Port C (Upper) - INPUT } \\
\text { D4 }=1 & \text { Port A - INPUT } \\
\text { D5 }=0 & \text { Group A - MODE "0" } \\
\text { D6 }=0 & \\
\text { D7 }=1 & \text { Mode Set Flag - Active }
\end{array}
$$




\section{PROGRAMMABLE PERIPHERAL INTERFACE: 8255A - DEVICE 1}

CONTROL WORD FOR A WRITE OPERATION (A4H)

CONTROL ADDRESS $=$ F7H

\begin{tabular}{|l|l|l|l|l|l|l|l|l|}
\hline $\mathrm{D} 7$ & $\mathrm{D} 6$ & $\mathrm{D} 5$ & $\mathrm{D} 4$ & $\mathrm{D} 3$ & $\mathrm{D} 2$ & $\mathrm{D} 1$ & $\mathrm{D} 0$ \\
\hline 1 & 0 & 1 & 0 & 0 & 1 & 0 & $\mathrm{x}$ \\
\hline
\end{tabular}

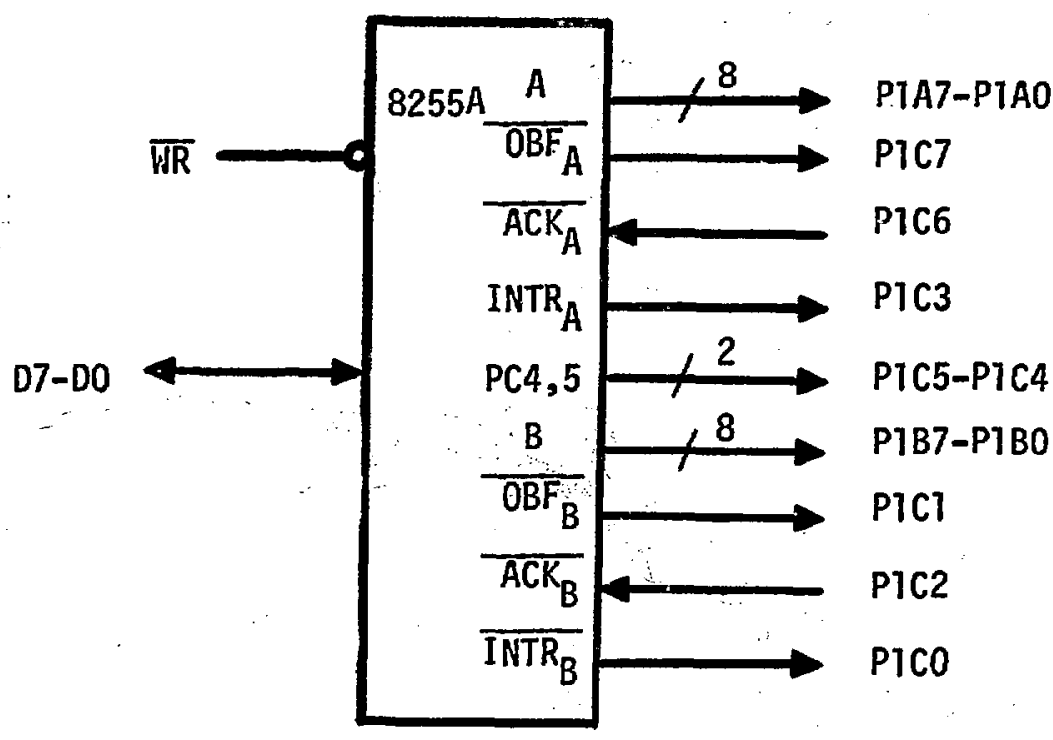

$$
\begin{array}{ll}
\text { DO }=x & \text { Don't Care } \\
\text { D1 }=0 & \text { Port B - DUTPUT } \\
\text { D2 }=1 & \text { Group B - MODE "1" } \\
\text { D3 }=0 & \text { Port C4,5- OUTPUT } \\
\text { D4 }=0 & \text { Port A - OUTPUT } \\
\text { D5 }=1 & \text { Group A - MODE "1" } \\
\text { D6 }=0 & \\
\text { D7 }=1 & \text { Mode Set Flag - Active }
\end{array}
$$

- Software ACK Bit PIC4 is inverted and tied to PIC6 $\overline{\text {ACK}_{A}}$ and PIC2 $\overline{\text {ACK}_{B}}$ and is controlled via a Bit Set/Reset Command.

- PIC5 is tied to Output Disable $(\overline{O D})$ of the Data Link RAM. 
PROGRAM PERIPHERAL INTERFACE: 8255A - DEVICE 1

READ OR WRITE DATA:

P1A7 P1A6 P1A5 P1A4 P1A3 P1A2 P1A1 P1A0

\begin{tabular}{|l|l|l|l|l|l|l|l|}
\hline RW8 & RW7 & RW6 & RW5 & RW4 & RW3 & RW2 & RW1 \\
\hline
\end{tabular}

DATAL (PORT A) ADDRESS $=$ F4H

P1B7 PIB6 PIB5 PIB4 PIB3 PIB2 P1B7 P1B0

\begin{tabular}{|l|l|l|l|l|l|l|l|}
\hline RW16 & RW15 & RW14 & RW13 & RW12 & RW11 & RW10 & RW9 \\
\hline
\end{tabular}

DATAH (PORT B) ADDRESS $=\mathrm{F} 5 \mathrm{H}$

\section{SINGLE BIT SET/RESET FEATURE OF THE 8255A}

Any of the eight bits of Port $C$ can be Set or Reset using a single OUTPUT instruction.

CONTROL WORD

\begin{tabular}{|c|c|c|c|c|c|c|c|}
\hline $\mathrm{D} 7$ & $\mathrm{D} 6$ & $\mathrm{D} 5$ & $\mathrm{D} 4$ & $\mathrm{D} 3$ & $\mathrm{D} 2$ & $\mathrm{D} ?$ & $\mathrm{D0}$ \\
$\mathrm{0}$ & $\mathrm{X}$ & $\mathrm{X}$ & $\mathrm{X}$ & $\mathrm{I}-0$ & $\mathrm{I}-0$ & $1-0$ & $1-0$ \\
\hline
\end{tabular}

$$
\begin{aligned}
& \text { DO }=1 \text { Bit Set } \\
& \text { DO }=0 \quad \text { Bit Reset } \\
& \text { D1 }=1-0 \\
& \text { D2 }=1-0 \text { Bit Select } \\
& \mathrm{D} 3=1-0 \\
& D 7=0 \quad \text { Bit Set/Reset Flag - Active }
\end{aligned}
$$




\section{$\mu \mathrm{p}-\mathrm{DL}, \mathrm{JI}$ PIN ASSIGNMENTS}

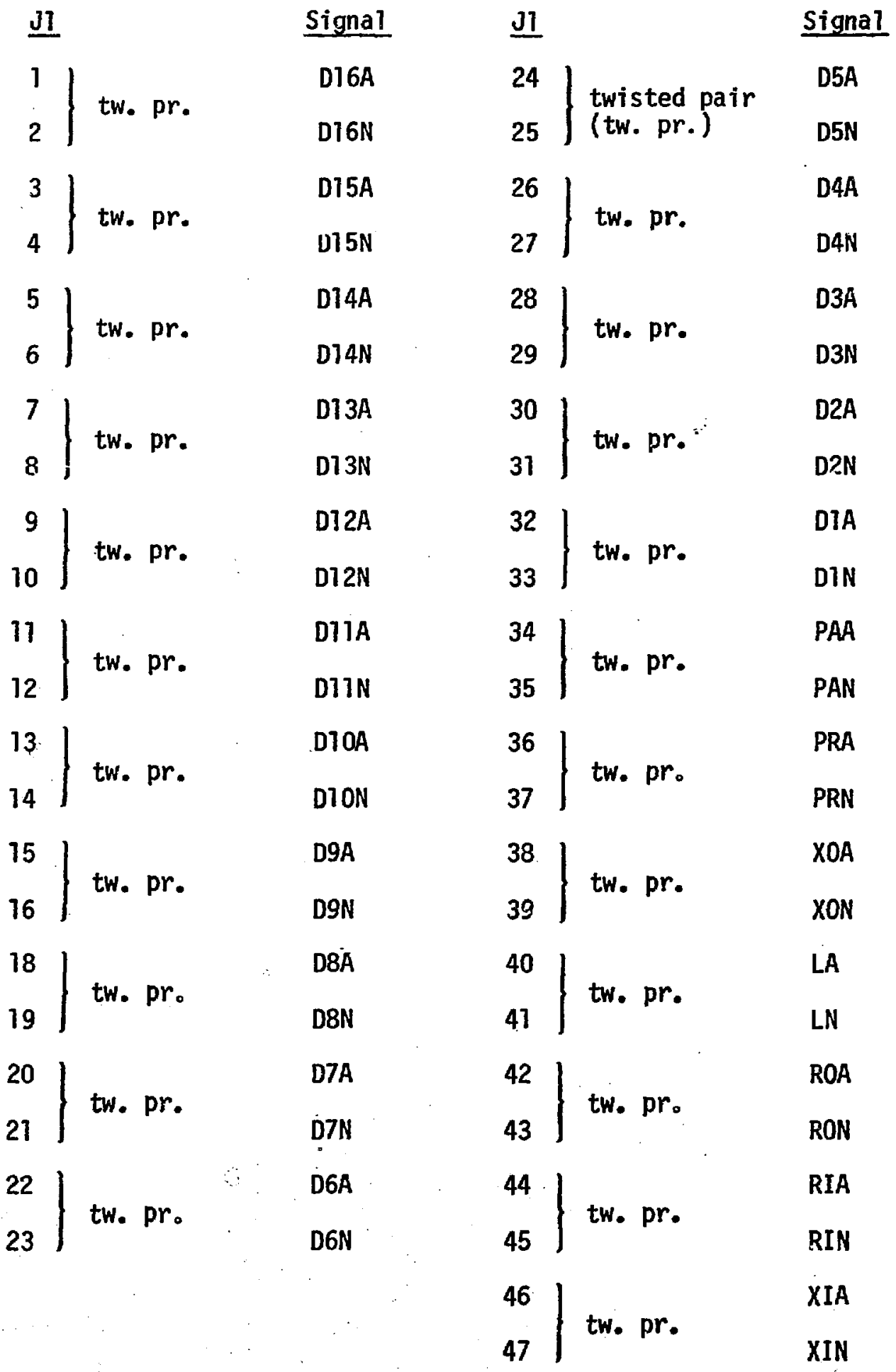


AMP, 50 contact connectors No. 205212-1

AMP, Connector Shield and Cable Clamp Assembly No. 205732-1

AMP, Pins No. 205310-8 for No. 26 twisted-pair wires

AMP, Pins No. 205202-4 for No. 22 twisted-pair wires

BELDEN, 23-pair Cable No。 9749

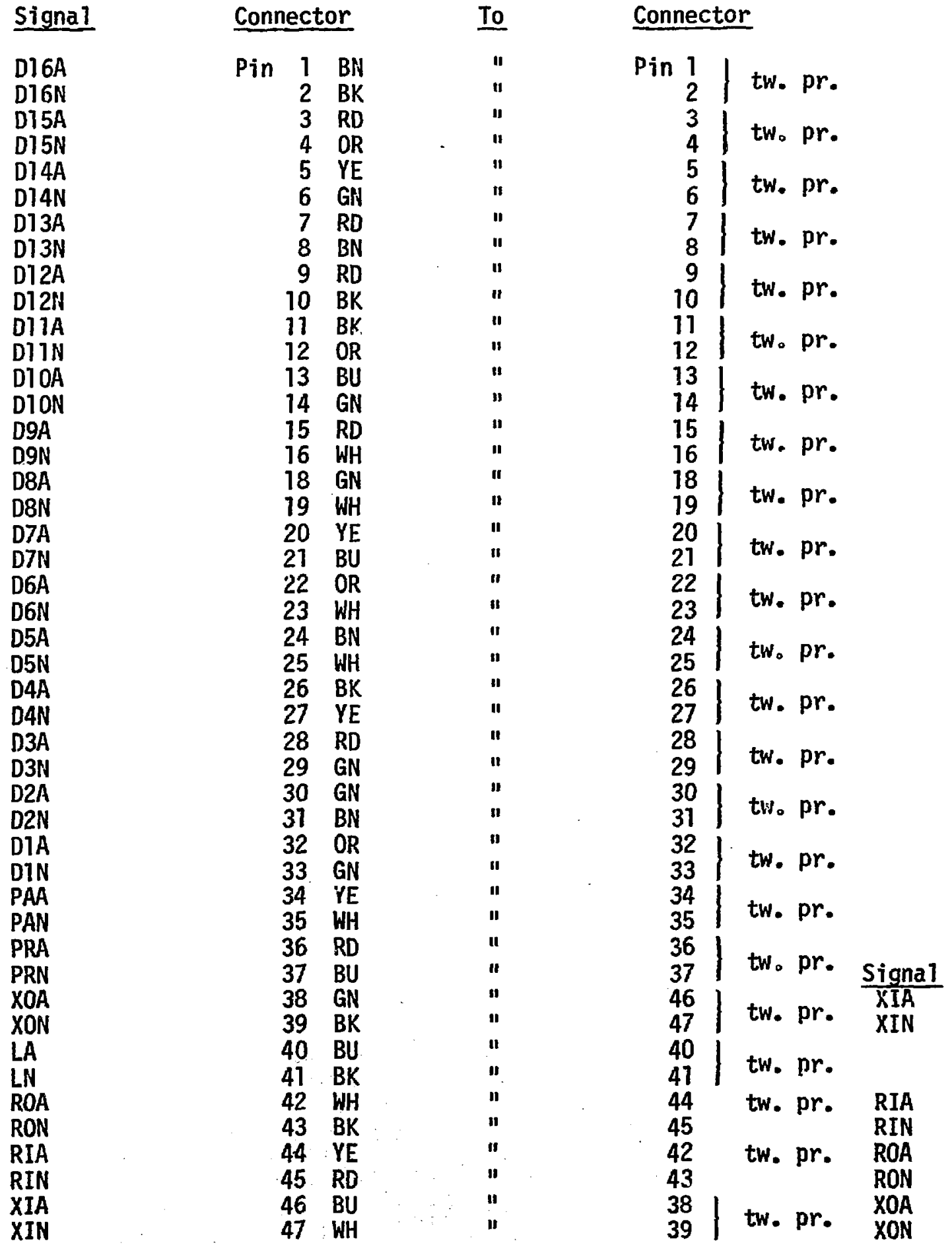




\section{APPENDIX A}

\section{LOGICAL FLOW DIAGRAMS}

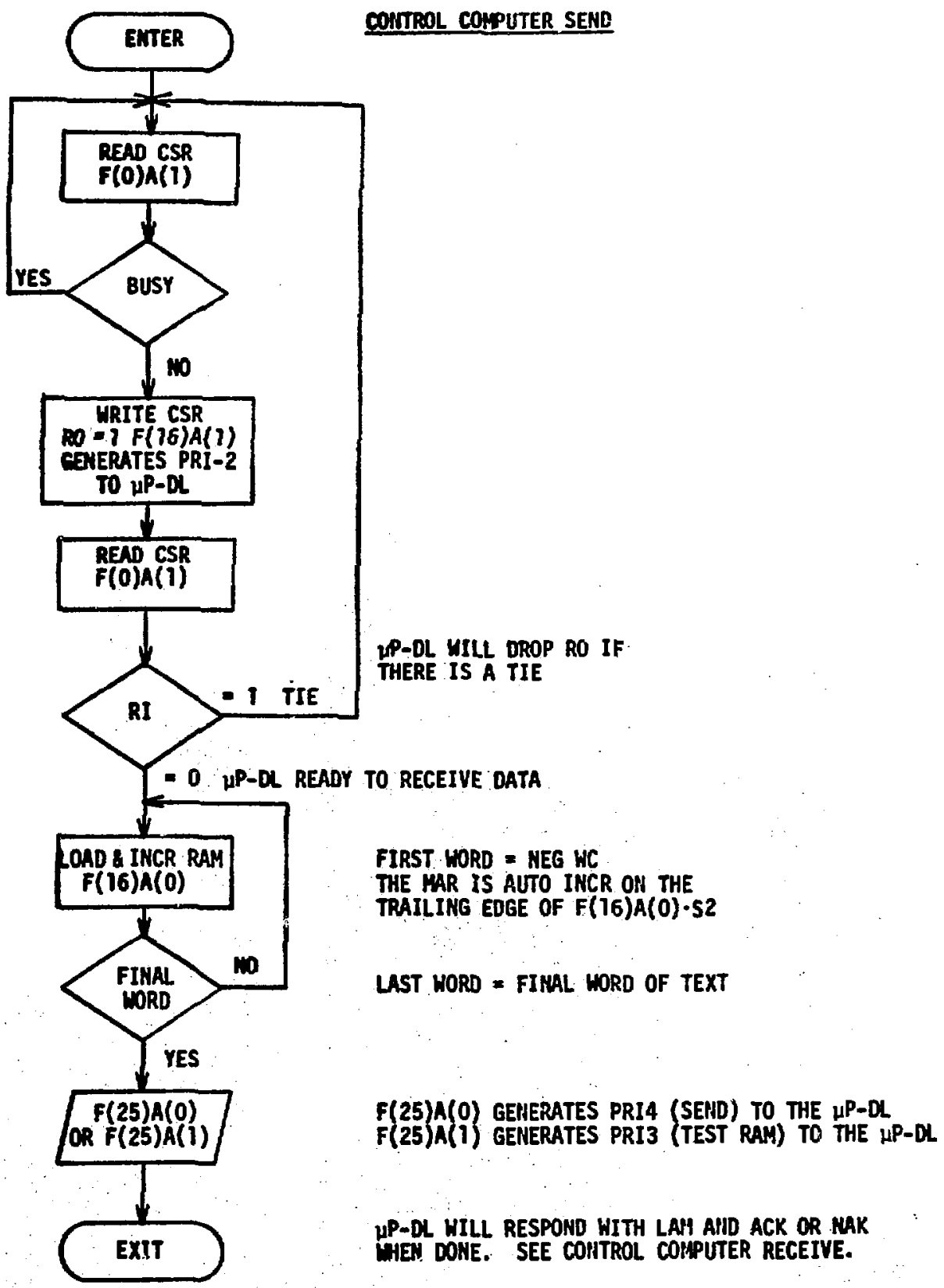




\section{COIIM COHUIER RECEIYE}

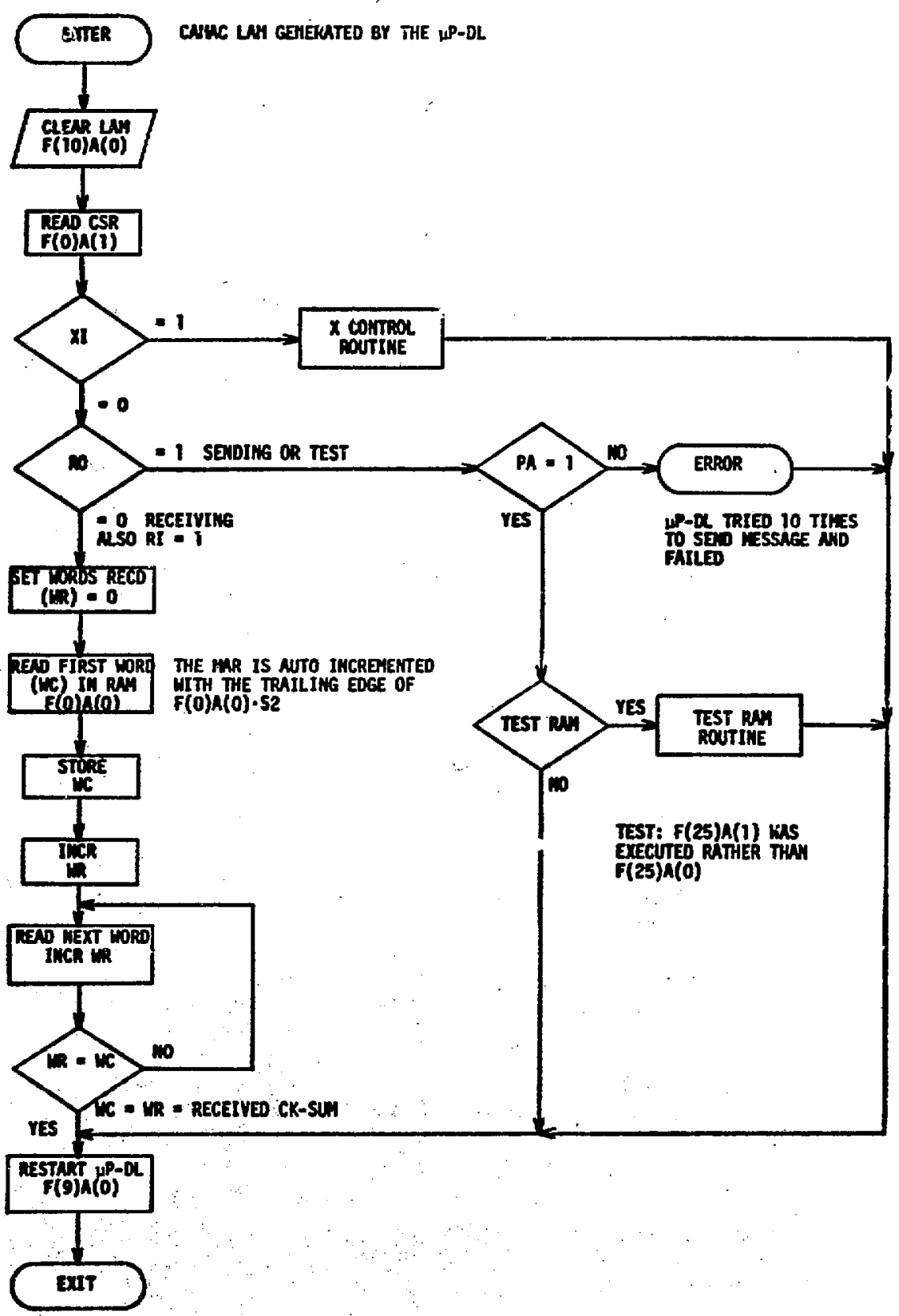


840 CONTROL COIIPUTER SEND DOHN-LINE LOAD TO POP-11 VIA $\mu P-O L$

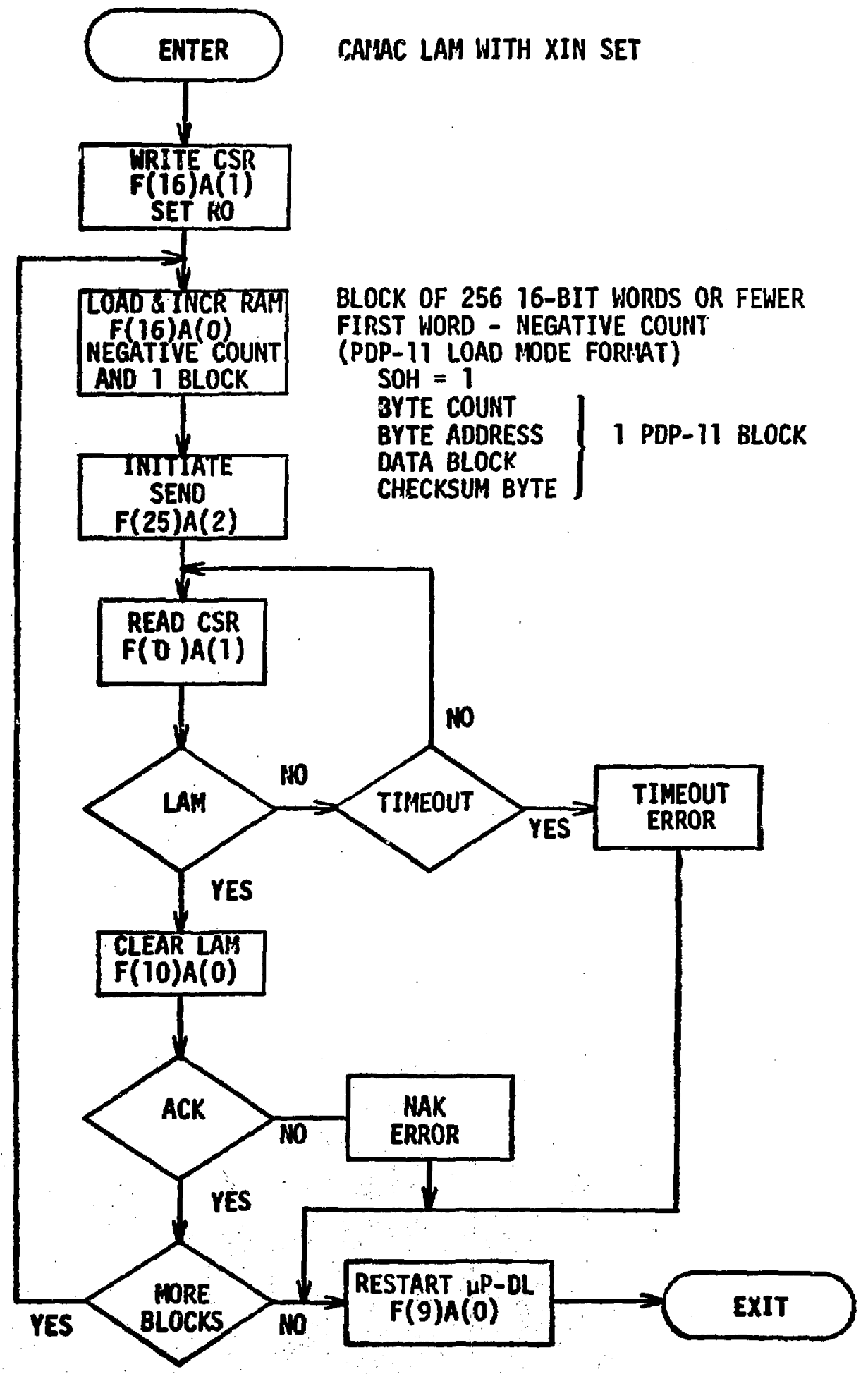




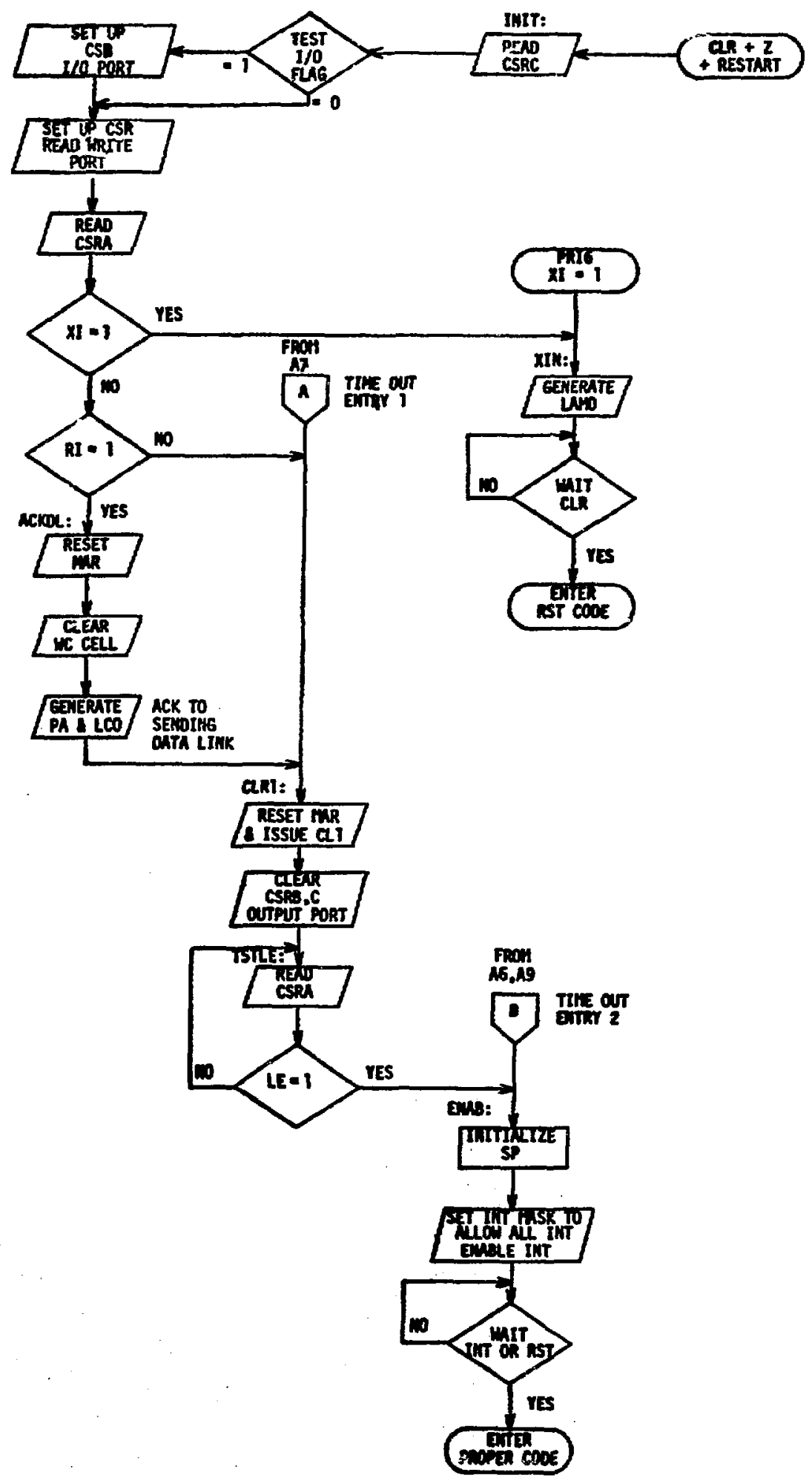


$\mu P$-DL INTERRUPT TO WRITE THE CONTROL STATUS REGISTER

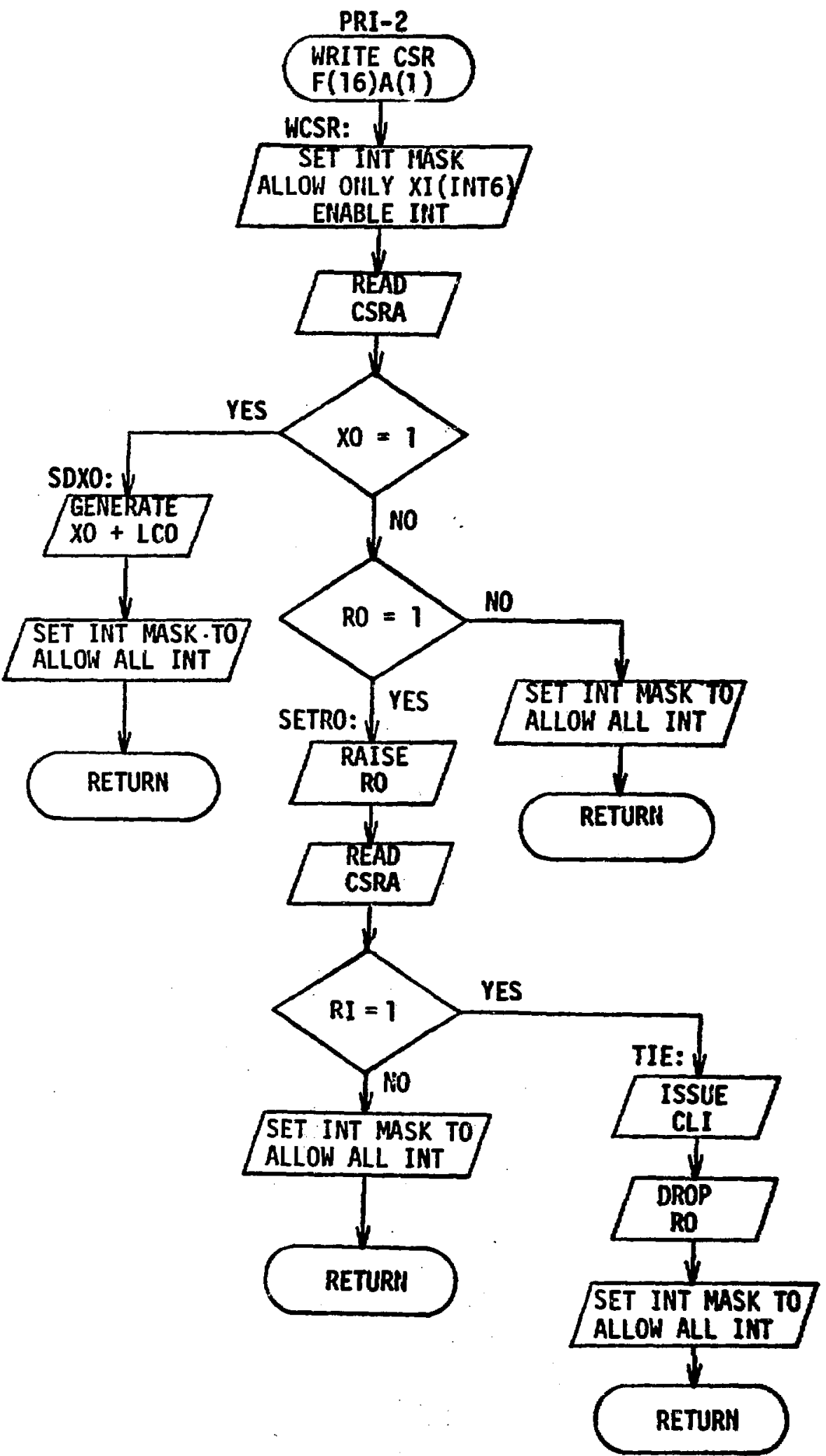




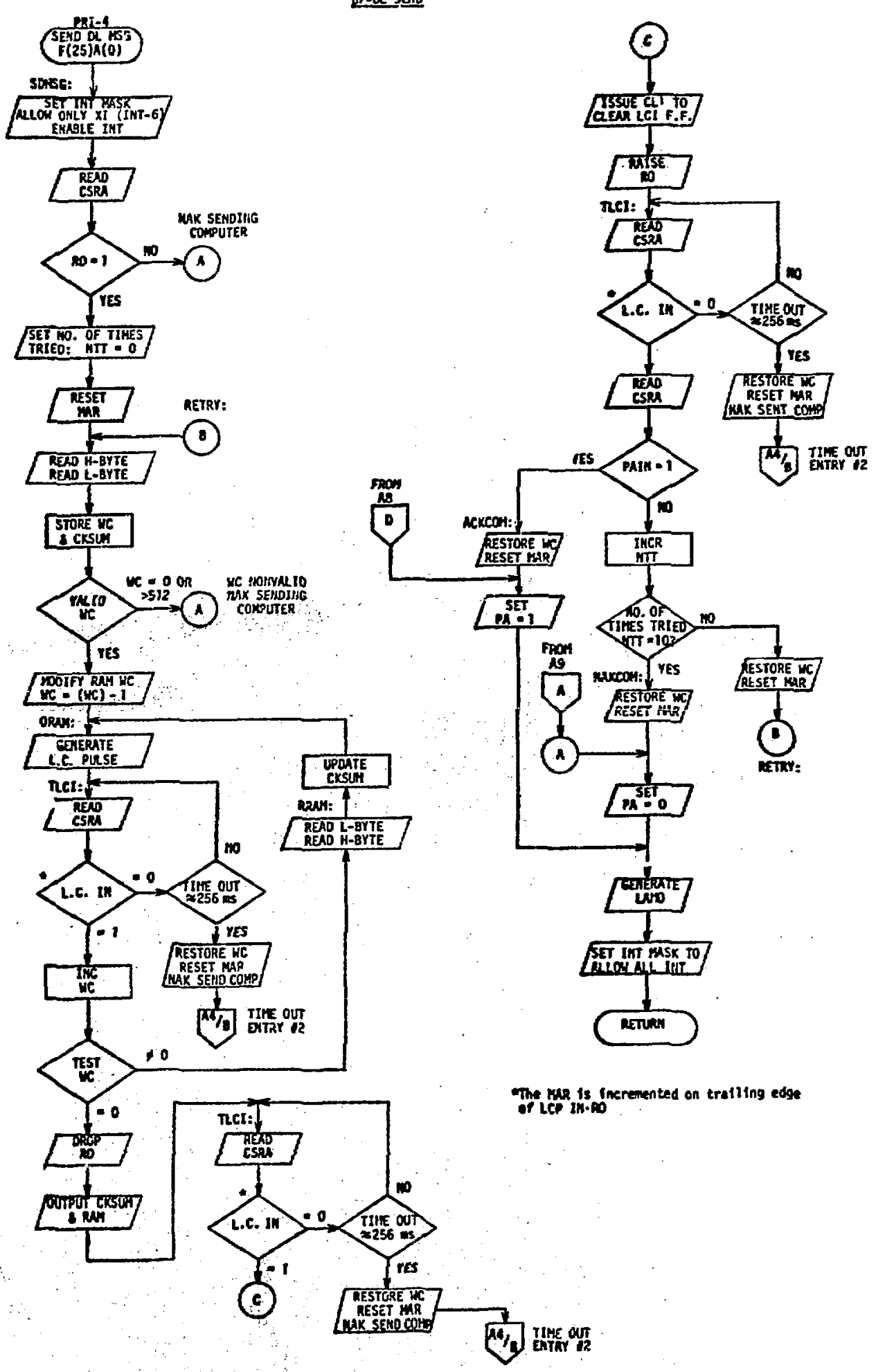




\section{WP-QL RECEIVE}

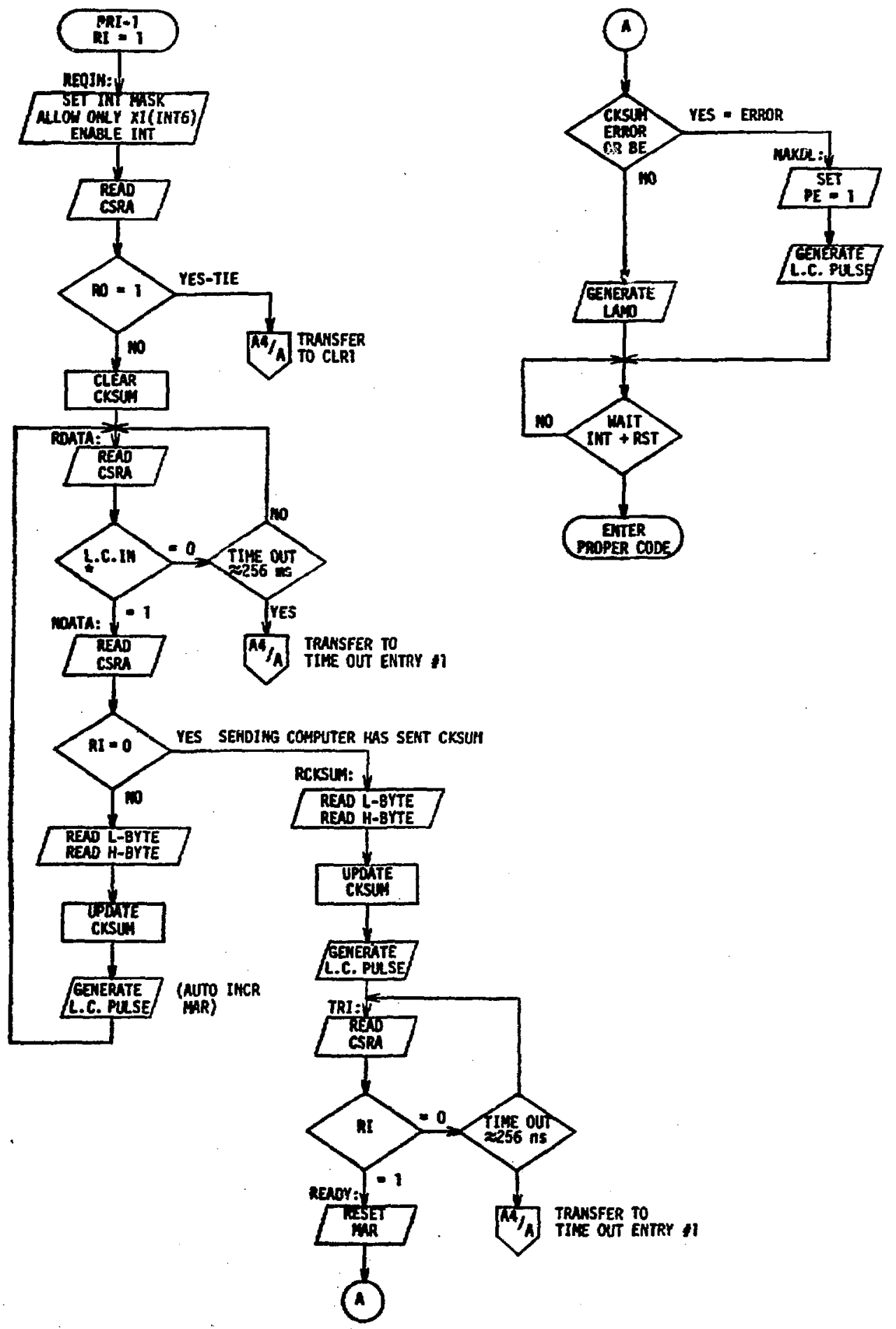

Datu strobed into RM when L.C. pulse is recelved 


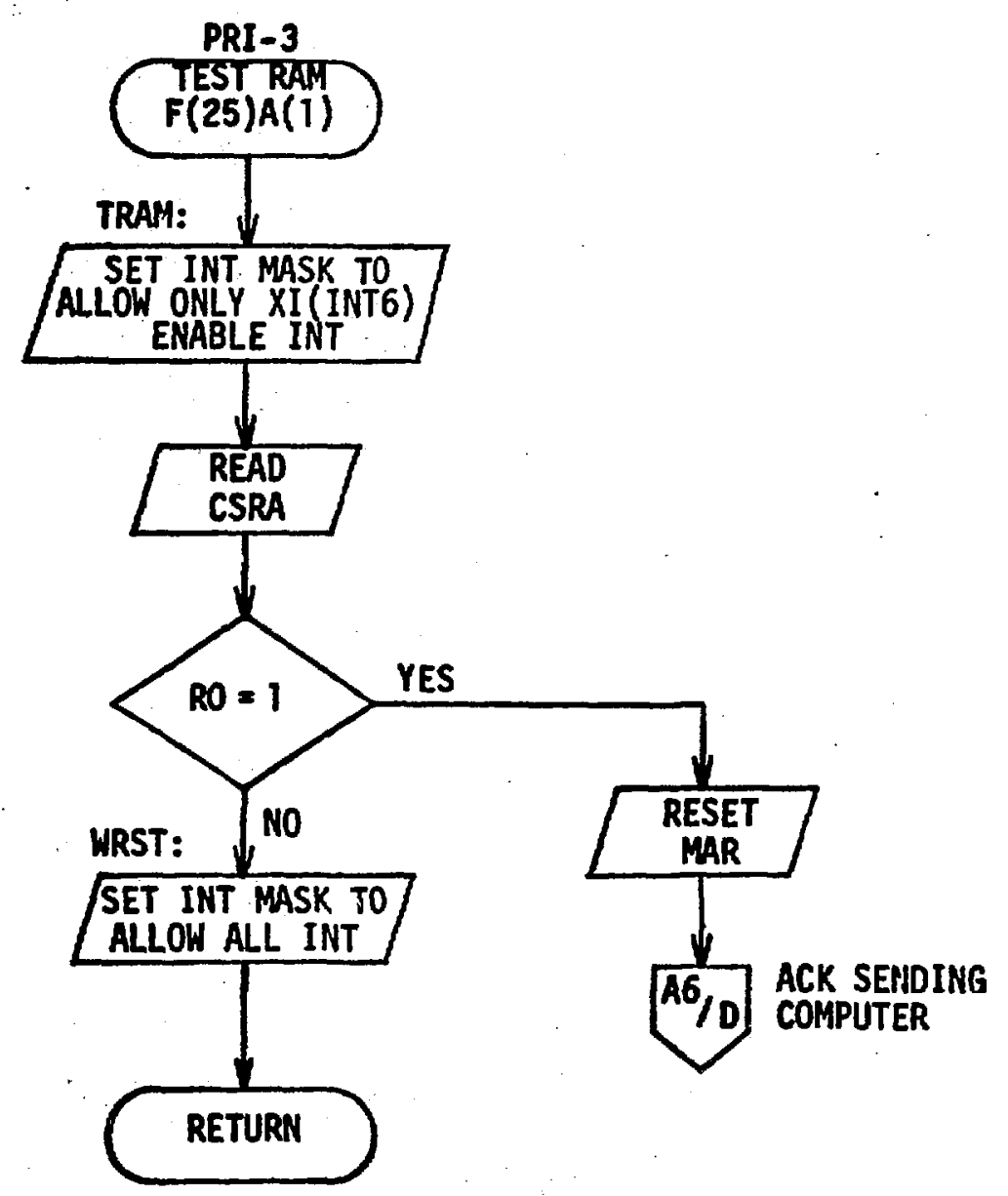




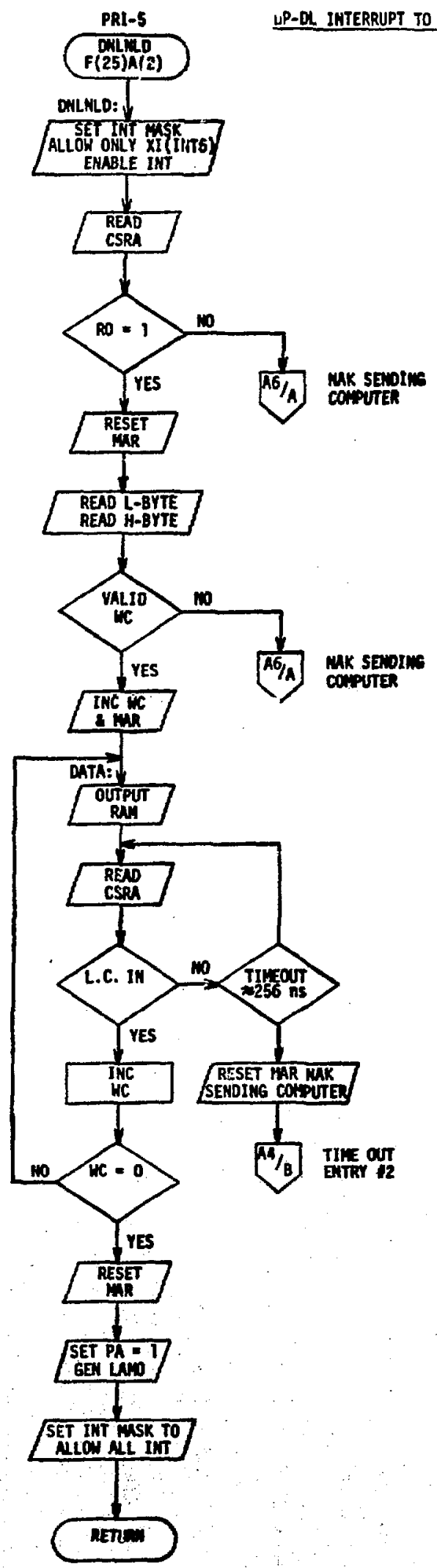




\section{APPENDIX - B}

\section{PROGRAM LISTING}

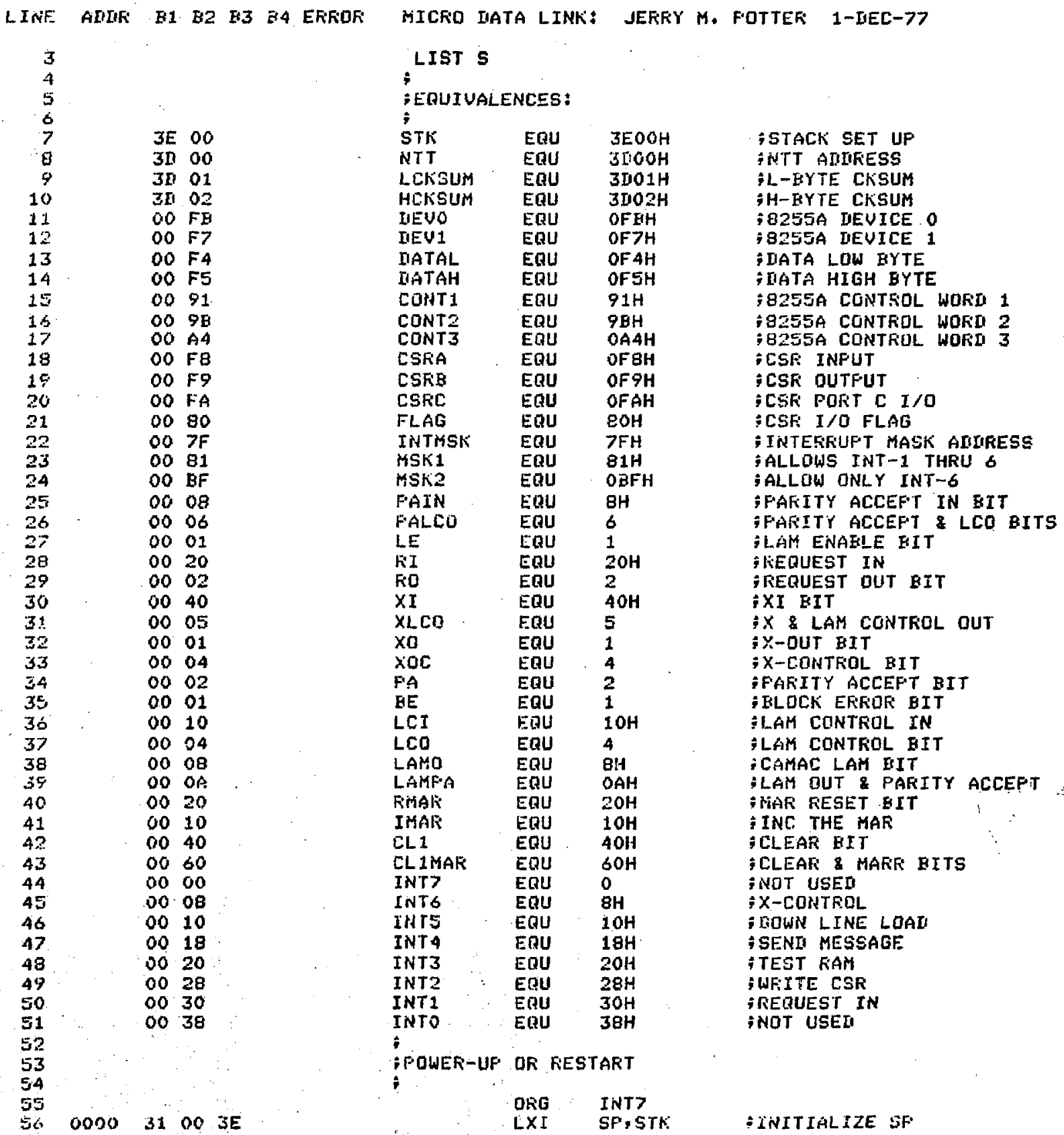




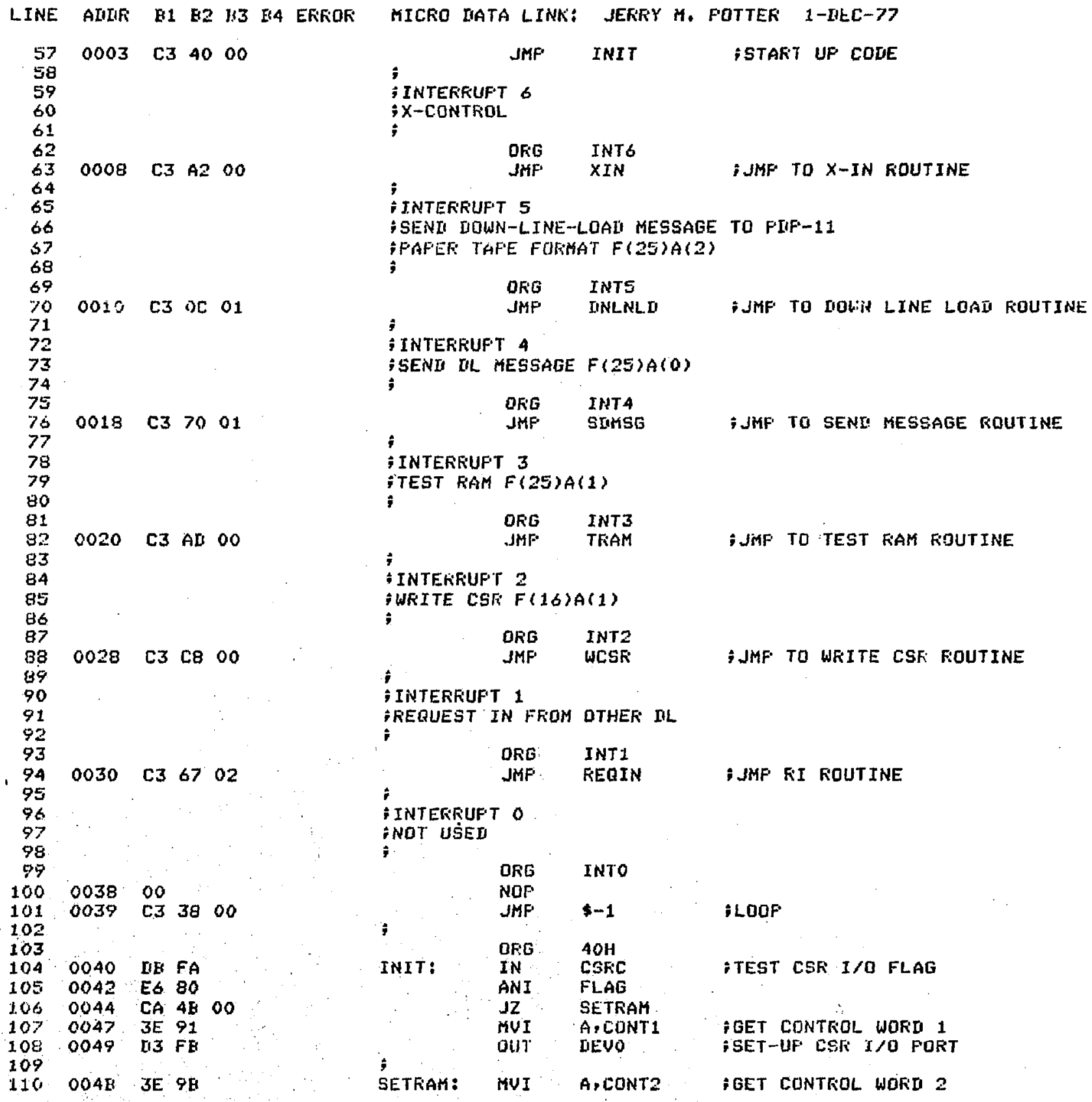




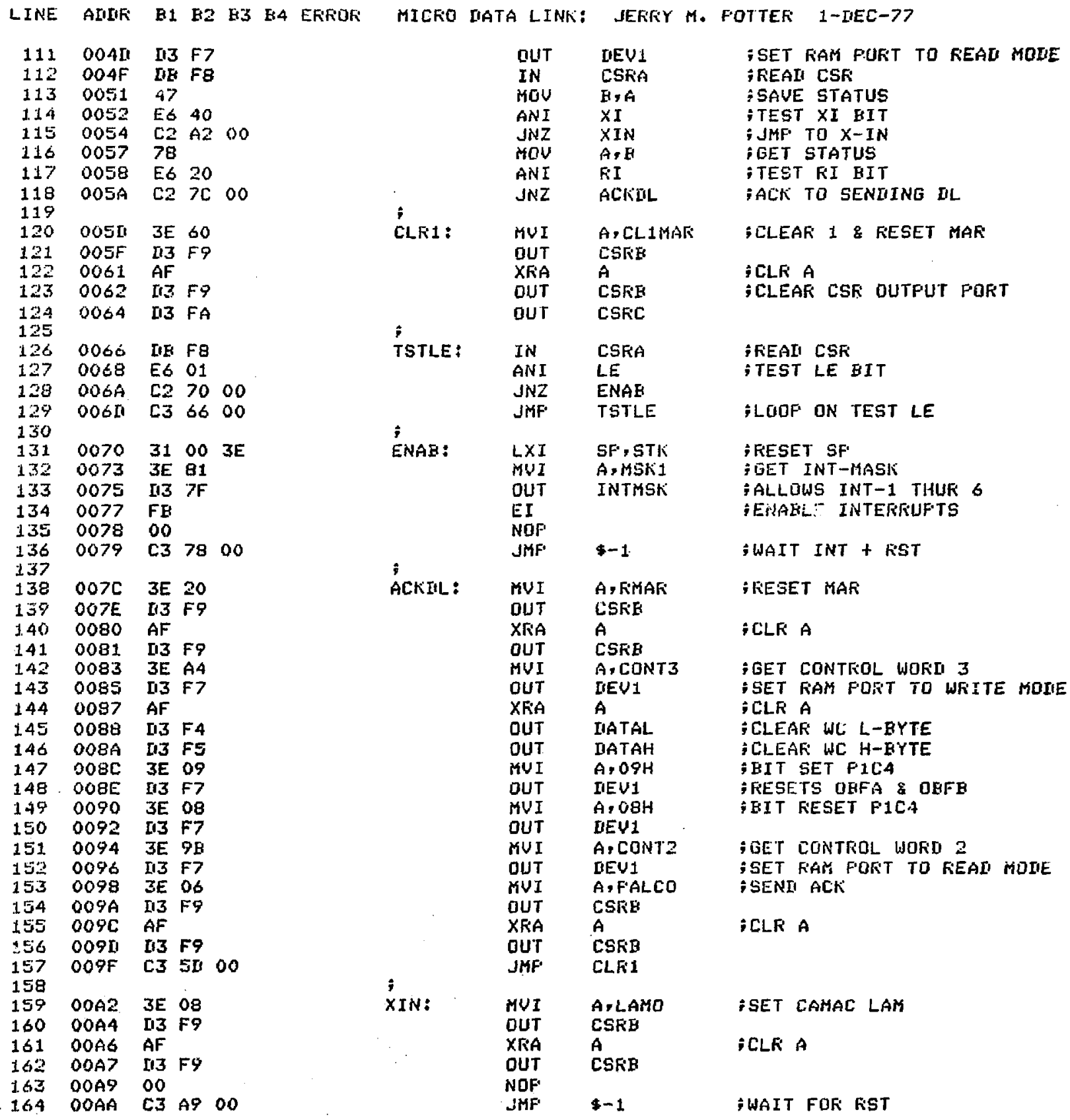




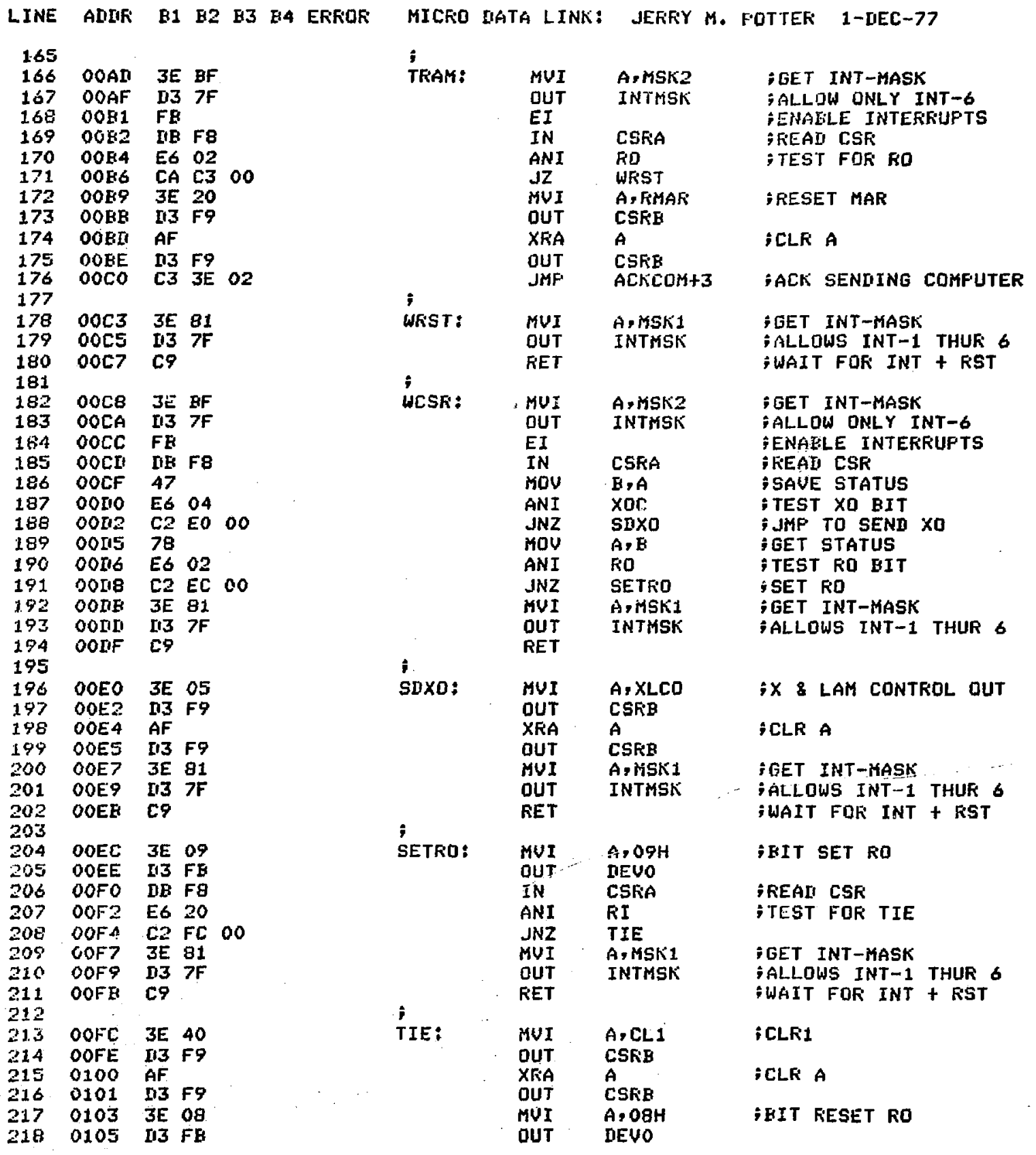




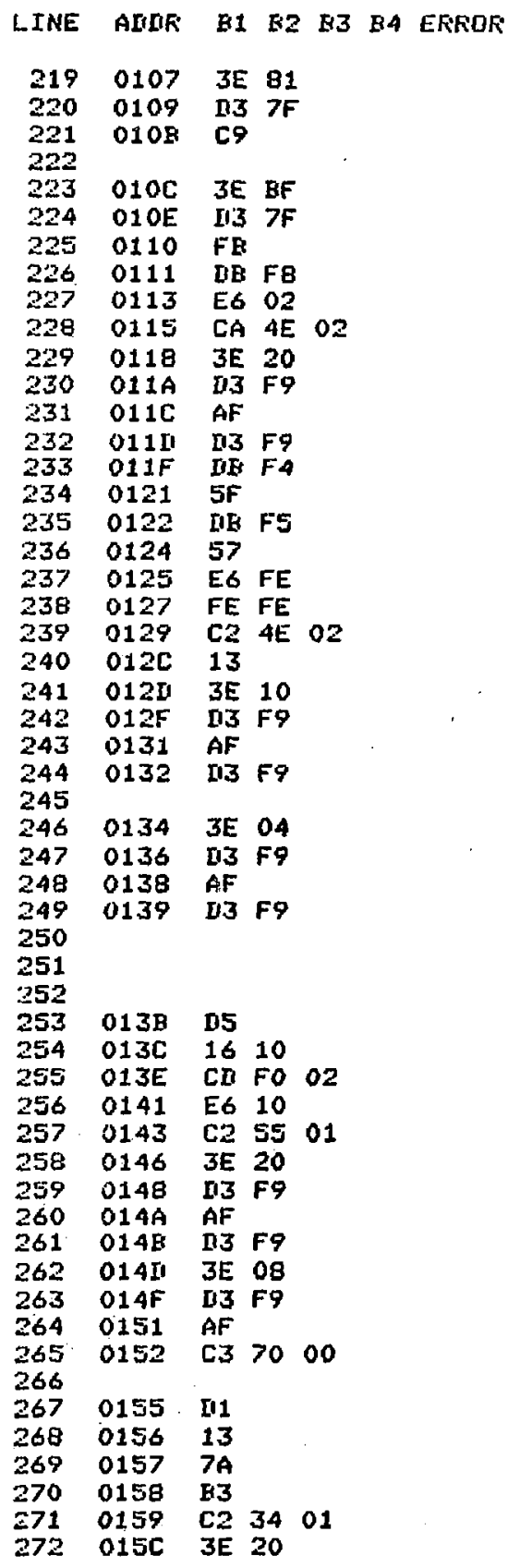

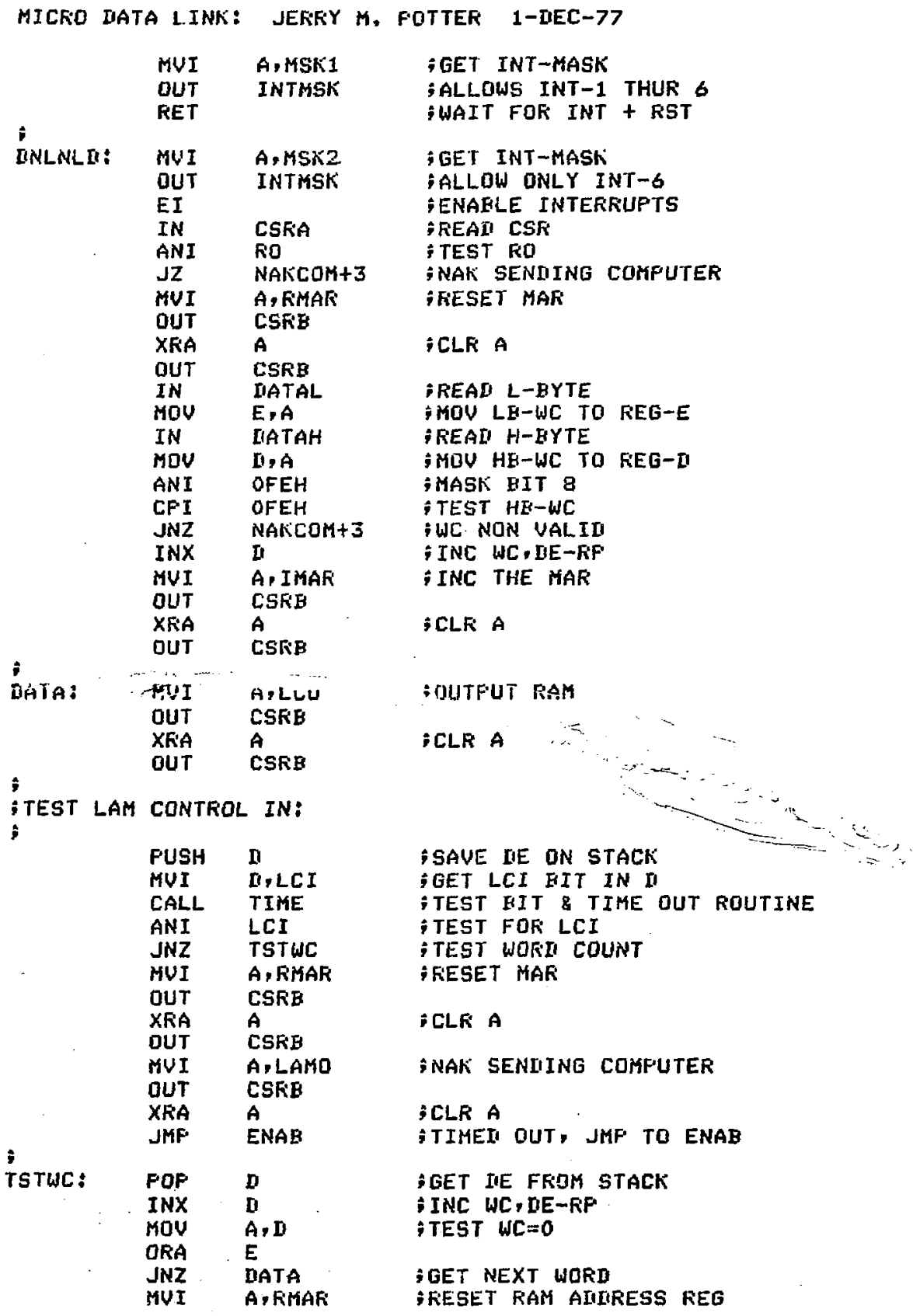




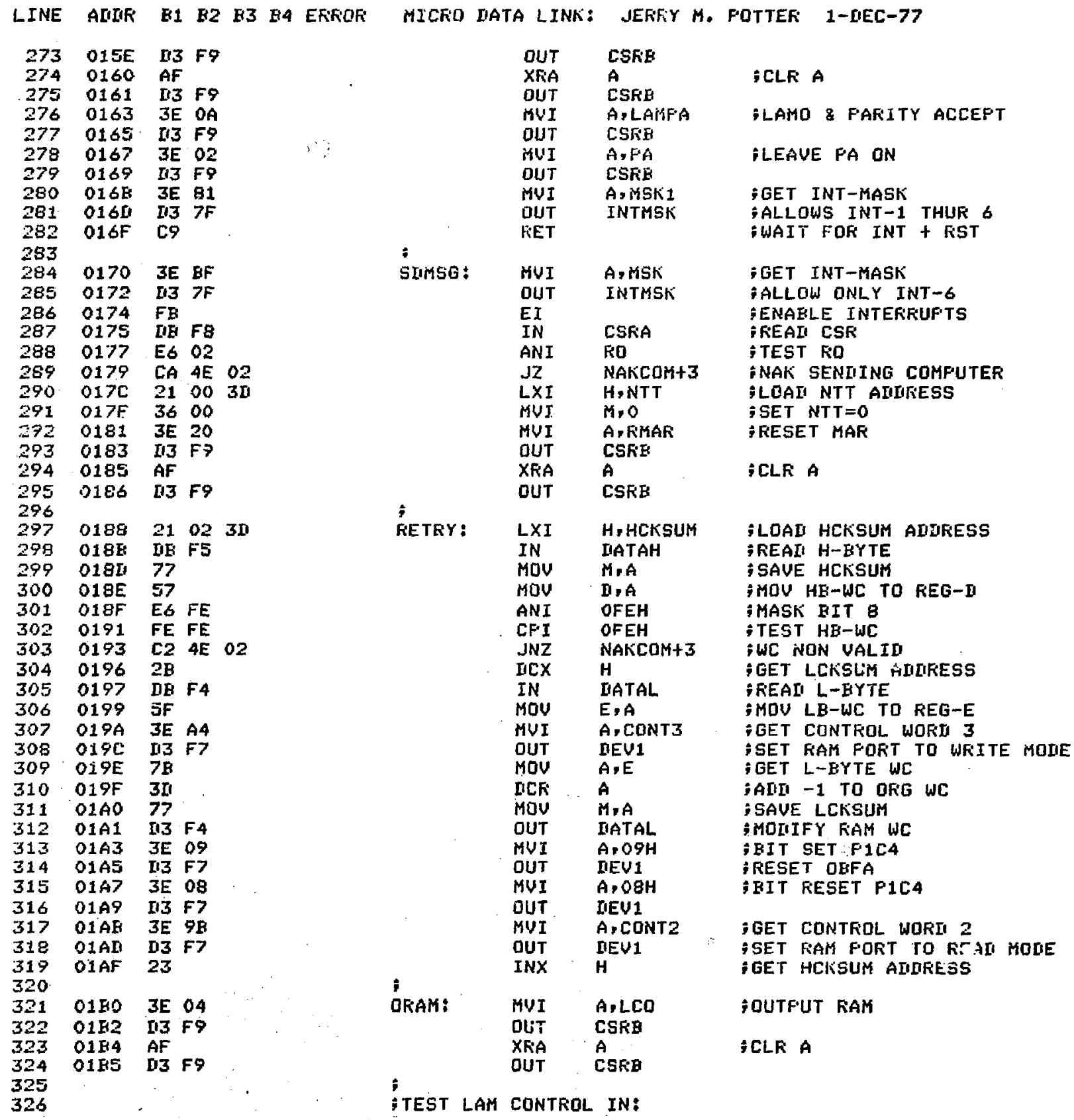




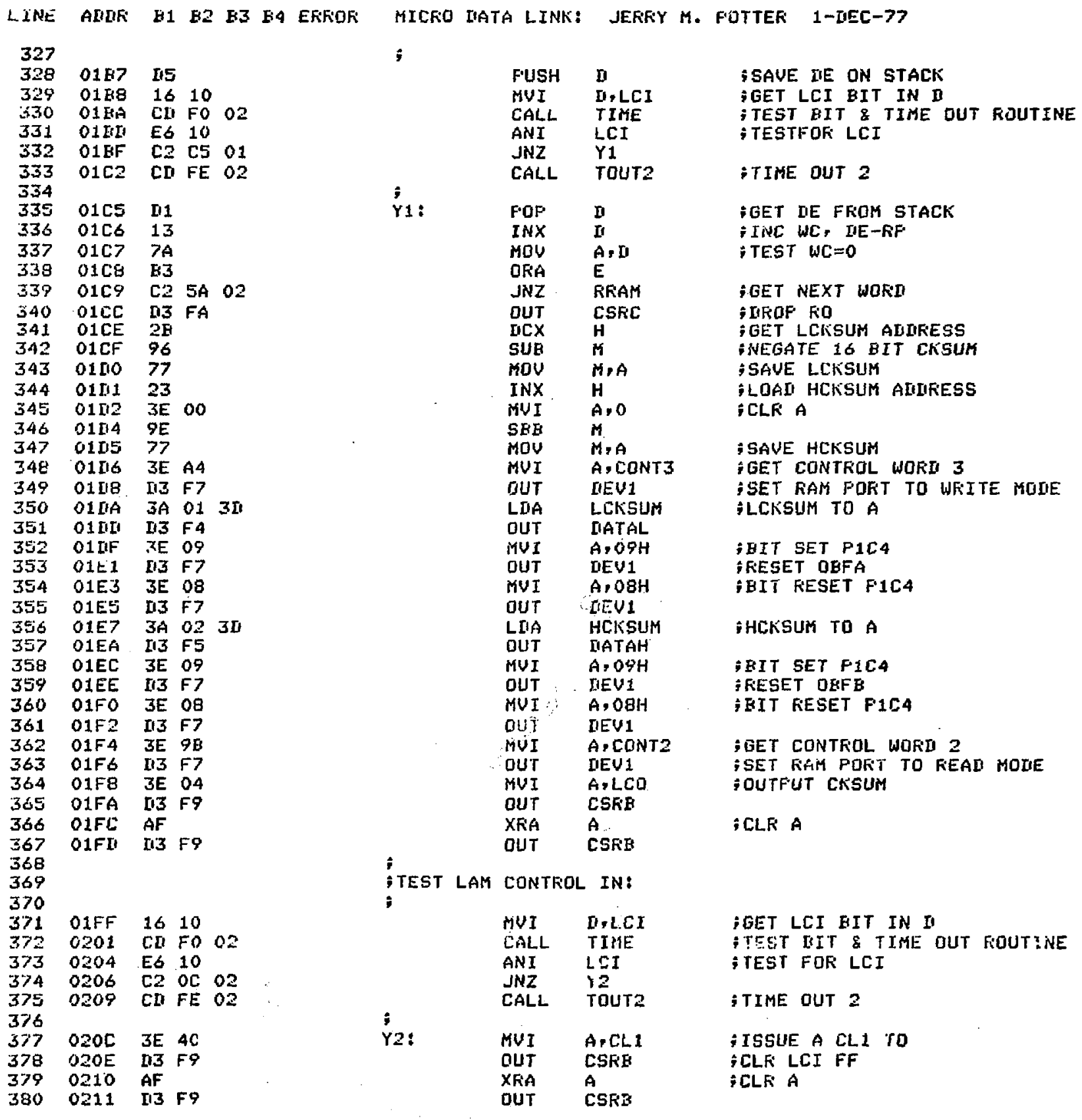




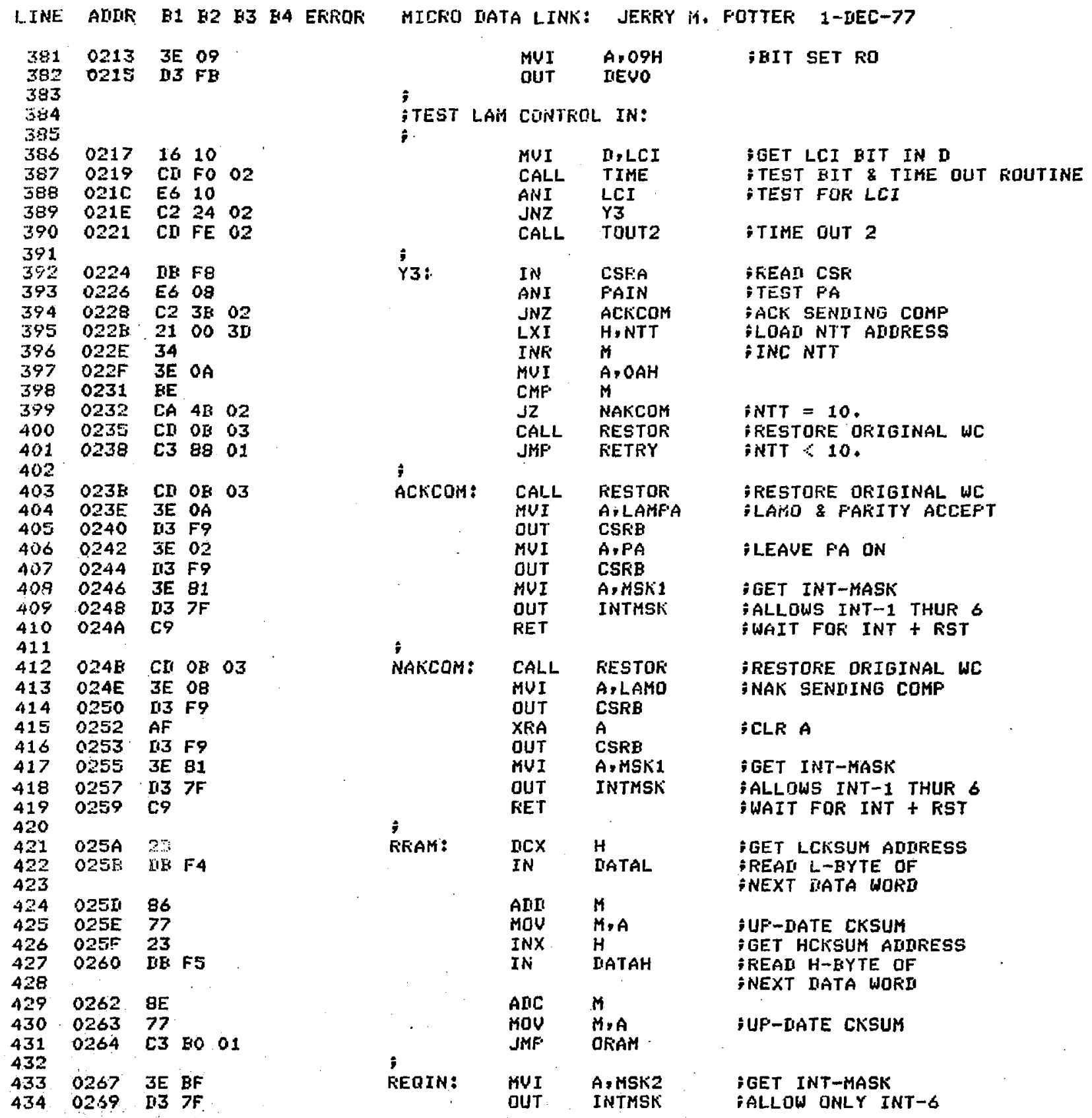




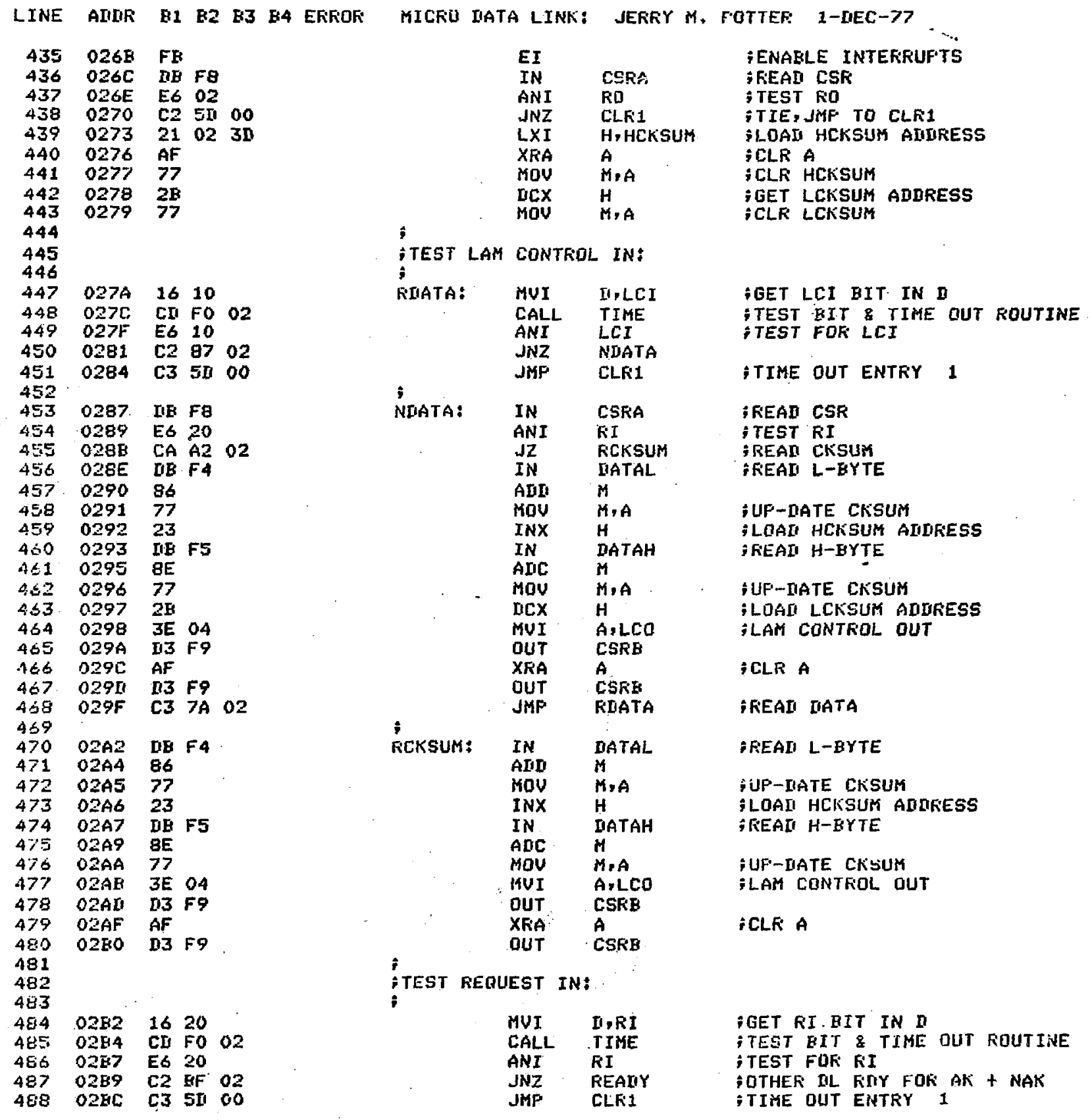




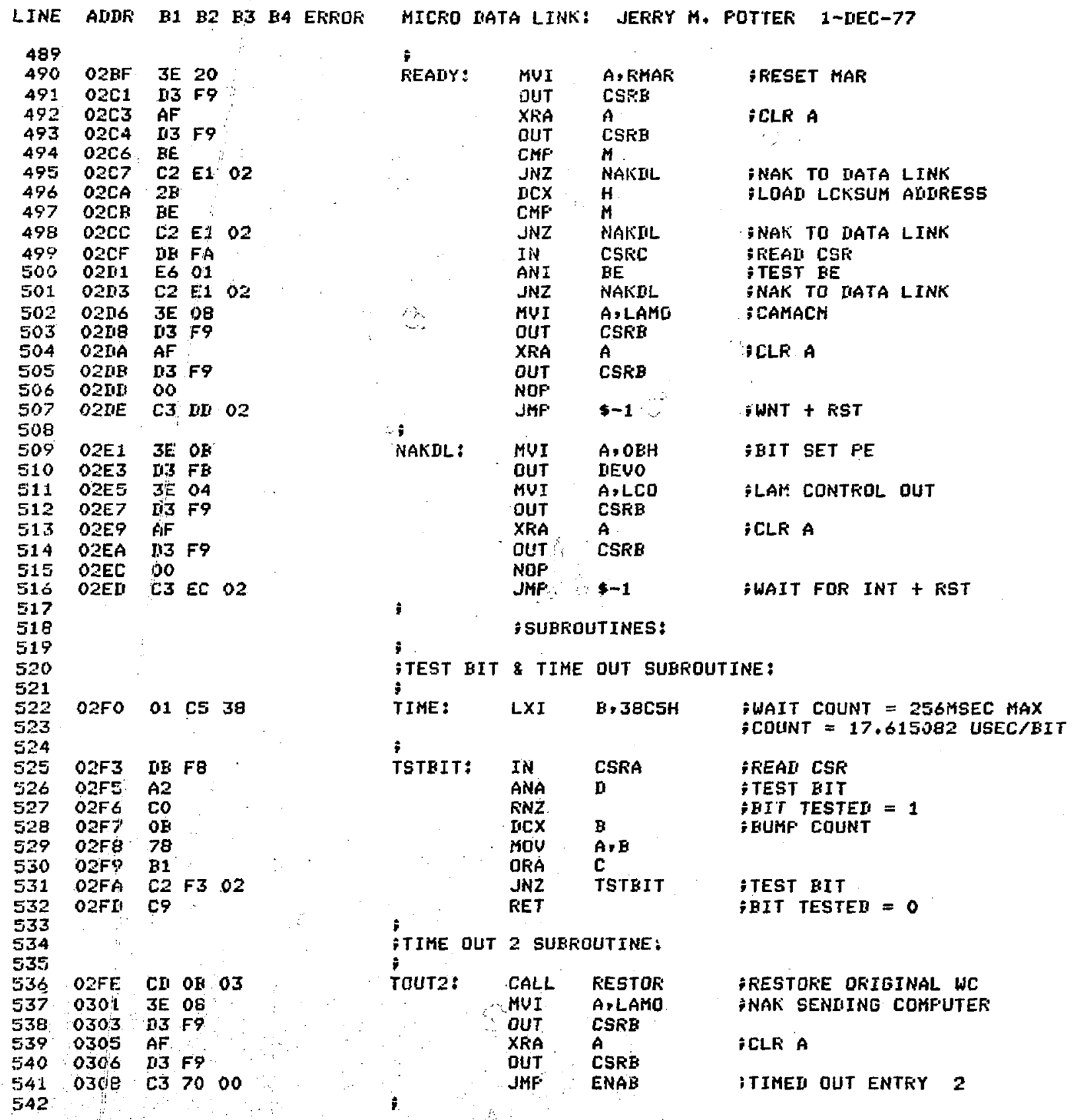


LINE AINR E1 B2 H3 E4 ERROK

543

545 O3OE 3E 20

546 030II IIJ F9

547 O30F AF

$548 \quad 0310$ II3 F9

$549 \quad 0312$ IH F4

$550 \quad 0314$ 5F

ज51 0315 उE A4

$\begin{array}{llll}552 & 0317 \quad 13 \quad 57\end{array}$

$553 \quad 0319 \quad 7 \mathrm{~B}$

554 031A 3C

555 031E $113 \mathrm{F4}$

550 O31D 3E 09

557 O31F D3 F7

$558 \quad 0321$ 3E 08

559 0323 D3 F7

560 0325. 3E 95

5.61. 0327 II3 F7

$562 \quad 0329 \quad 09$

$563 \quad 032 \mathrm{~A}$

TOTAL ASSEMELEF EFROFS =
MICKO IIATA LINK: JERFYY M. FOTTEF: 1-IIEC-77

; FESTORE ORIGINAL WC SUEROUTINE:

7

\begin{tabular}{|c|c|c|c|}
\hline FESTOR: & $\begin{array}{l}\text { MUI } \\
\text { OUT } \\
\text { XRA } \\
\text { OUT } \\
\text { IN } \\
\text { MOU } \\
\text { HUI } \\
\text { OUT } \\
\text { HOU } \\
\text { INR } \\
\text { OUT } \\
\text { HUI } \\
\text { OUT } \\
\text { MUI } \\
\text { OUT } \\
\text { WUI } \\
\text { DUT } \\
\text { RET } \\
\text { ENI }\end{array}$ & $\begin{array}{l}\text { A,FIMAF } \\
\text { CSFE } \\
\text { A } \\
\text { CSFI } \\
\text { IIATAL } \\
\text { E,A } \\
\text { A, CONT3 } \\
\text { IEVI } \\
\text { A,E } \\
\text { A } \\
\text { IATAL } \\
\text { A,OSH } \\
\text { IEUI } \\
\text { A,OBH } \\
\text { DEVI } \\
\text { A, CONT2 } \\
\text { DEU1 }\end{array}$ & 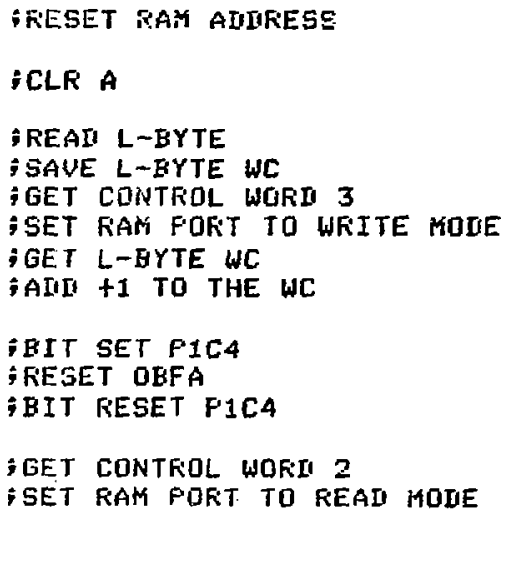 \\
\hline
\end{tabular}

0

MICKO IIATA LINK: JEKFIY M. FOTTER 1-IEEC-77

SYMEOL TAELE

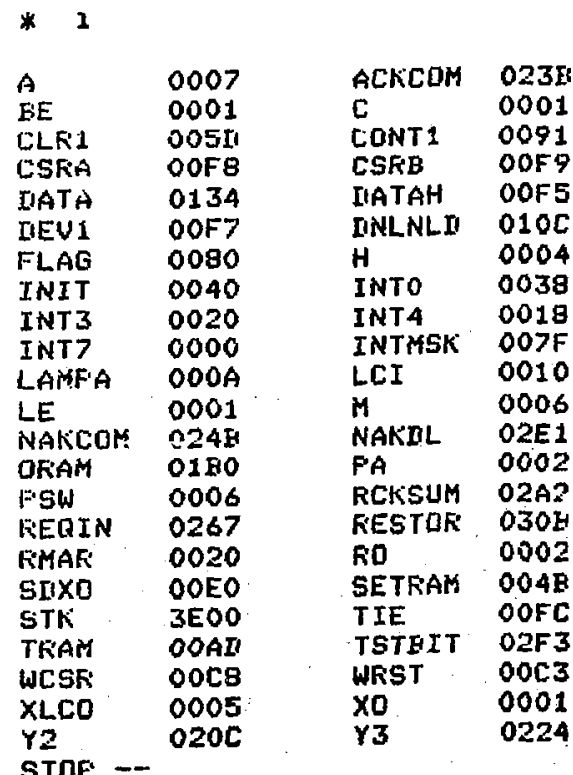

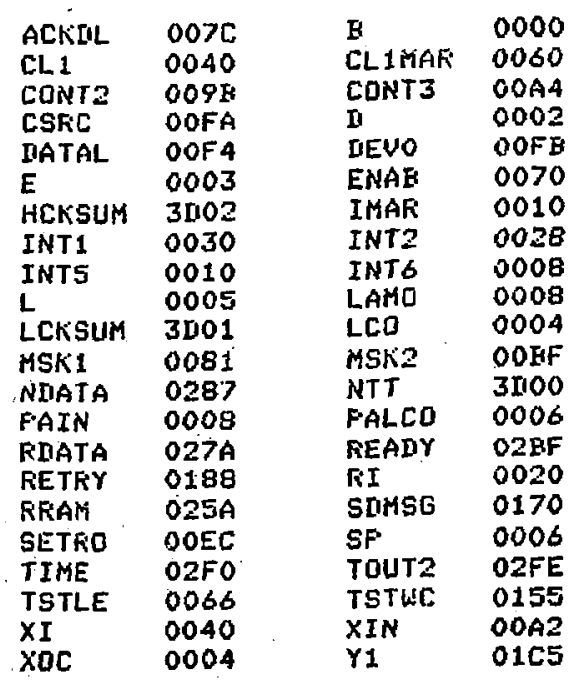


F: FIF

* $r$ :IX1:U[L + OEJ

$: 0600000031003 E C 3400088$

:03000800C3A20090

$\$ 03001000 \mathrm{C} 30 \mathrm{C011II}$

:05001800C37001B1

$: 03002000 \mathrm{C} 3 \mathrm{AT1006 \textrm {D }}$

$103002800 \mathrm{C} 3 \mathrm{E} 3004 \mathrm{~A}$

$03003000536702 A 1$

$0400380060133900 C 9$

1.E004000LEFAEGQ0CA4FO03E91 D3FE3E9BL3F 7IIFFB47E640C2A20078E620C27C003E74

:1E00SE0060I3F9AF D3F9D3FAIHEBE601C27000C36600310C3E3E81[I37FFB00C3780045

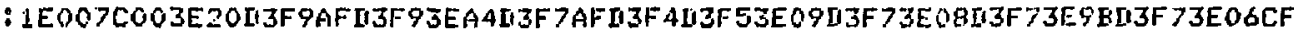

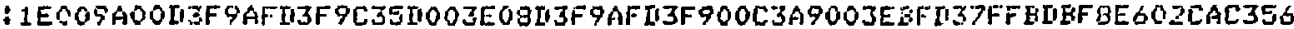

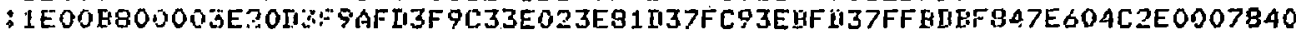

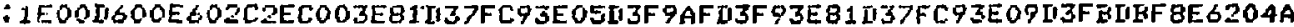

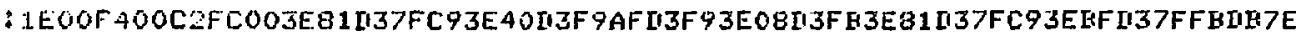

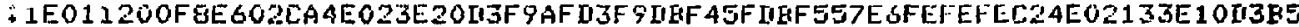

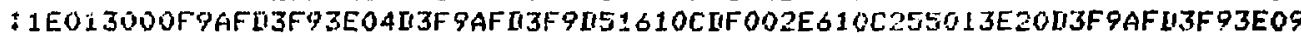
: 1E014E000ELJF9AFC37000L1137AB3C234013E20I3F9AFI3F93E0AL3F93E02I3F 93ED2

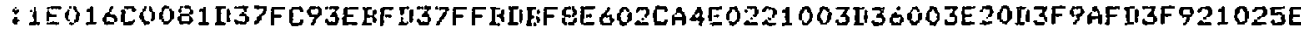

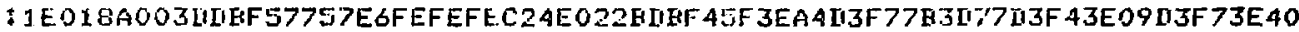

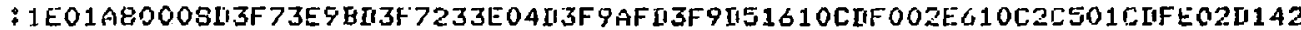

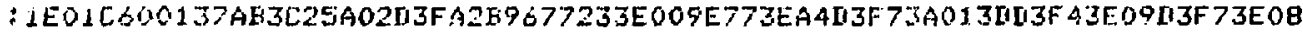

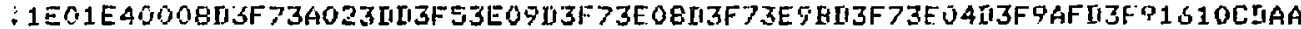

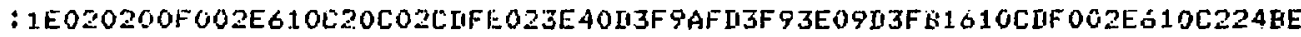

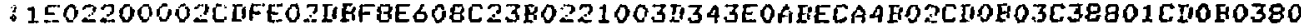

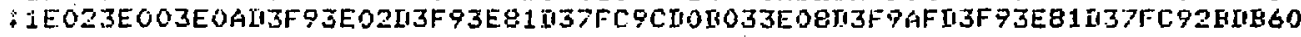
: 1E025COOF 4867723IEF5AE77C3\$0013EEFI37FFEMEF8E602C25I10021023UAF772B77[UE 1E027A001610CLF002E610C28702C35UOOLIRFBE620CAA202IEF 4867723DEF58E772EEA

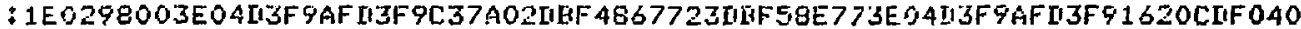

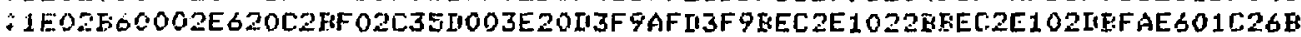

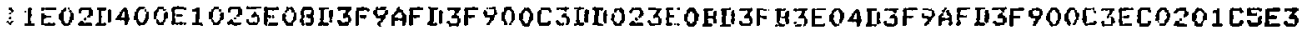

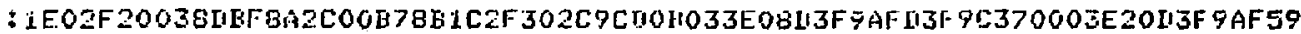

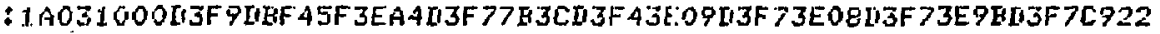
$: 0000000000$ 